\title{
IN THE RIGHT PLACE AT THE RIGHT TIME: A REVIEW OF MOBILE LOCATION-BASED MARKETING AND A RESEARCH AGENDA
}

\author{
Annaysa Salvador Muniz Kamiya \\ $\mathrm{PhD}$ in Business Administration \\ Centro Universitário FEI \\ São Paulo, SP - Brazil \\ annaysamuniz@gmail.com
}

Diana Sinclair Pereira Branisso Master in Business Administration FGV Eaesp São Paulo, SP - Brazil diana.branisso@fgv.br

Objective: Based on the increasingly pervasive mobile presence in the retail context, the purpose of this study is to examine the potential effects of the mobile message content and geolocation data as drivers of store visits, connecting online efforts to offline behavior.

Method: This article provides a review of the literature of what is known about mobile marketing, location-based communication, and push-notification effects on customer attitudes and behavior.

Results: The study synthesize arguments for location-based push notifications related to visits to offline sites, coupon offers, and personalized and high-engagement content. Based on numerous findings from marketing and customer research, it identifies a set of general propositions.

Theoretical/methodological contributions: This review intends to contribute to theories of mobile marketing, omnichannel customer behavior as well as the understanding of geolocation promotions. By identifying strategies that marketers employ for more effective geolocation promotions, this review provides an overarching framework to synthesize current findings in mobile location-based marketing and identifies gaps in our current knowledge in order to stimulate additional work in this field.

Managerial implications: The main assumption behind the article is that the content and the timing of the message (considering the customer's geolocation) increase visits to offline sites. Context and convenience as the primary drivers of the effect (visits to offline POS generated by mobile notifications), considering that context and convenience are represented by geolocation and message content. This provides the base for a mobile model for companies to attract customers to physical locations This review contributes by shedding light on the path to mobile activation in a cross-channel retail strategy.

Keywords: Geolocation. Location-Based Marketing. Mobile Marketing. Retail. Traffic Acquisition.

How to cite the article

American Psychological Association (APA)

Kamiya, A. S. M., \& Branisso, D. S. P. (2021, Apr./June). In the right place at the right time: a review of mobile location-based marketing and a research agenda. Brazilian Journal of Marketing, 20(2), 199-225. https://doi.org/10.5585/remark.v20i2.18713. 


\section{Introduction}

“Allow Instagram to access your location?” Installing new mobile applications (apps) usually comes along with this well-known notification. Many apps (e.g.: Strava ${ }^{\mathrm{TM}}$, AccuWeather ${ }^{\mathrm{TM}}$, Trip Advisor ${ }^{\mathrm{TM}}$, Facebook ${ }^{\mathrm{TM}}$ ) continuously track user location in exchange for providing underlying services, such as determining the distance you have run, the local weather forecast, directions to nearby destinations or to check on a location to share with friends. Other apps, however, do not directly provide underlying services. Instead, they analyze user data retrieved through mobile geolocation tracking in order to design much more assertive communication strategies, such as push notifications. In fact, smartphones are the most common personal device customers have today, and as such, they are one of the richest sources of data for retail conversion (Fulgoni \& Lipsman, 2016). However, mobile geolocation is a novel technology, and studies of its effects on customer responses are still scarce.

Mobile technologies are increasingly commonplace in business. In some countries, such as Brazil, the US, or the UK, the number of smartphones has surpassed that of notebooks (Comscore, 2018), revealing a global trend towards mobile use, taking over the majority of web browsing. In some countries, such as China, the US, Norway, and Russia, the digital channel has already become the dominant ad medium in expenditure and the most relevant channel (eMarketer, 2018). No recent technological innovation has had a more transformative effect on customers' lives than the virtually indispensable smartphone (Melumad \& Pham, 2020).

Push notifications are an important tool for the increase of retail sales via smartphones since they are a way to speak directly to a user, promoting products or offers, and converting unknown app users into known customers. However, according to the PushCrew Notifications Report (2018), 39.8\% of subscribers want more relevant and personalized notifications. More than $74 \%$ of the audience thinks that receiving more than 5 notifications a day is too many. Most people believed that push notification users should send fewer notifications and send personalized and relevant ones. Besides, there is a direct relationship between cancelled subscriptions the frequency of notifications. Cancelled subscriptions increase when frequency increases. That means, push notifications should be more targeted and accurate.

During the customer journey, mobile is mostly used for education, information, and engagement, not necessarily for the last click. Searching for online information before visiting a store creates an anticipatory itch which boosts desire. Yet, firms still struggle to measure how much to attribute to their mobile channel. Marketers are unclear about the degree to which the 
mobile channel drives revenue and profitability, which is the challenge of determining accurate attribution (Bakopoulos et al., 2017). Hence, rather than focusing only on driving more sales via the mobile channel, research can also address mobile opportunities that arise which increase overall sales. That means understanding how the mobile channel can use push notifications to drive sales in physical stores.

Mobile researchers (Pantano \& Priporas, 2016; Beeck \& Toporowski, 2017; Verhoef et al., 2017; Grewal et al., 2018; Gutierrez et al., 2019; Högberg et al., 2020) recommend further studies regarding how to attribute online and mobile activities to offline store purchases. These studies indicate the need to systematically investigate the impact of mobile promotions on offline purchase behavior. Location-based push notification is a strategy particularly relevant to retailers because it enables them to attract customers to their stores, approaching customers when they are most receptive. Thus, understanding the potential of utilizing location technologies is an important research task that can make both theoretical and practical contributions.

As pointed out earlier, the impact of the mobile scenario on the shopping experience of brick-and-mortar customers is still underdeveloped (Pantano \& Priporas, 2016; Shankar et al., 2016), particularly in terms of understanding how location-based services and mobile messaging can be used to affect customer behavior (Högberg et al., 2020). Hence, the purpose of this study is to further knowledge of the possible effects of location-based mobile promotions on offline stores. Previous research has highlighted the importance of a deeper exploration of how online and offline marketing activities affect one another and also on understanding mobile opportunities as technology advances. Lamberton and Stephen (2016) recently have advocated that researchers focus on understanding the marketing value of aspects of mobile technology that allow marketers and/or customers to do things that cannot be done with non-mobile technology, such as geolocated ad targeting.

Although much is already known about various aspects of mobile marketing, statistics on online purchases generally reflect the stage of payments made by the online channel, known as last-click metrics. The effect of push notifications on an individual's visiting a shop has not yet received much systematic attention, despite the fact that relevant studies have recently become available. Therefore, a common thread of the first half of this article is that we will provide an overview of the appropriate studies on mobile marketing in the online-to-offline area $(\mathrm{O} 2 \mathrm{O})$. In the second half, we will advance a set of propositions that, in our view, capture this. 
We synthesize arguments for location-based push notifications related to visits to the offline site, coupon offers, and personalized and high-engagement content.

Therefore, we present a summary of the appropriate studies on mobile marketing in the online-to-offline area $(\mathrm{O} 2 \mathrm{O})$, which is currently the state of the art in push notification and geolocation research, taking an $\mathrm{O} 2 \mathrm{O}$ perspective and highlighting moderating contextual effects. Additionally, we identify research issues which require further work to ensure the continued successful development of mobile location-based marketing research and practices. By identifying strategies that marketers may employ for more effective geolocation promotions and presenting this set of propositions, we hope to stimulate further empirical research into this highly relevant marketing strategy.

\section{Mobile marketing}

Since the late 1990s, technology has advanced at a furious pace (Parasuraman \& Colby, 2015), including social media, automation, mobile payments, and the rise of mobile commerce. Customers have embraced mobile technology, using these devices for all sorts of purposes: purchases, payments, research, and engaging with other customers. Businesses are extending their reach to customers throughout mobile commerce as this sales channel increases in popularity. Understanding the latest advances in mobile marketing and what lies ahead is essential for both scholars and marketers in grasping the essential characteristics of today's digital customer. The use of mobile marketing has increased in recent years as customer mobile usage and receptivity have grown (Fong et al., 2015), but the replacement of the traditional point of sale is still unrealistic (Pantano \& Priporas, 2016). The shopping process has moved towards a reality that integrates, to say the least, offline and the online opportunities and functionalities. In this process, mobile is the hub of omnichannel marketing, enabling a connected customer experience (Verhoef et al., 2017). Hence, there is an increasing need for retailers to integrate physical retail settings with mobile opportunities and functionalities ( Pantano \& Priporas, 2016; Beeck \& Toporowski, 2017; Verhoef et al., 2017; Grewal et al., 2018). Regarding online to offline relationships, a better understanding of how mobile promotions affect offline customer behavior is needed.

According to Pantano and Gandini (2018), the intensive use of social media and digital communication technologies has emerged as an integral part of the shopping experience inside and outside of stores. It does not mean, however, that online and offline retailers are following separate paths. The boundaries are fluid, and there are many possibilities for convergence. For 
example, responsive retail websites or apps can expedite a buyer's search for buying or delivering from a store (Shankar et al., 2016). Therefore, a company's offline operational capacity is equally important to meet the needs of online purchases (Tang et al., 2016). A retail presence today presents a dynamic that goes beyond the dichotomy of the physical or digital environment. It is understood today that channels are not exclusive: customers can relate to the physical and digital channels at different times throughout the shopping experience (Dholakia et al., 2010). The location-sensitive nature of smartphones opens the way for communication that is sensitive to the location of the customers (Högberg et al., 2020).

In fact, mobile marketing is a set of practices that enables organizations to communicate and engage with their audience in an interactive and relevant manner through, and with, any mobile device or network. Most recently, the mobile channel has been analyzed using the online-to-offline $(\mathrm{O} 2 \mathrm{O})$ model. Among other things, the $\mathrm{O} 2 \mathrm{O}$ model looks at online as a discovery mechanism for customers, which works as a foot traffic generator for merchants that facilitates offline purchasing. However, as Chiang et al. (2018) point out, there is still a need for a complementary model for companies to attract additional customers to physical stores. Pantano and Priporas (2016) highlight the importance of integrating retail physical configurations with online opportunities. Searching for purchases at collection points is a perceived benefit which avoids delivery problems and allows customers to check merchandise, which reduces risk (Pantano \& Priporas, 2016). In addition, offline shopping offers the possibility of product inspection and the social aspects of the shopping experience. On the other hand, online shopping offers the benefit of convenience, removing temporal and spatial barriers. 
Table 1 - Mobile Marketing research - most cited studies

\begin{tabular}{|c|c|c|c|c|c|c|c|}
\hline \multirow{3}{*}{ Authors } & \multirow{3}{*}{ Main findings } & \multicolumn{6}{|c|}{ Citations } \\
\hline & & 2016 & 2017 & 2018 & 2019 & 2020 & Total \\
\hline & & 435 & 551 & 591 & 908 & 468 & 4090 \\
\hline Shankar, Venkatesh, Hofacker, and Naik (2010) & $\begin{array}{l}\text { Mobile consumer activities, mobile consumer segments, mobile adoption enablers } \\
\text { and inhibitors, key mobile properties, key retailer mobile marketing activities } \\
\text { and competition. }\end{array}$ & 35 & 30 & 27 & 35 & 17 & 229 \\
\hline Shankar and Balasubramanian (2009) & $\begin{array}{l}\text { Drivers of mobile device/service adoption, the influence of mobile marketing on } \\
\text { customer decision-making, the formulation of a mobile marketing strategy, and mobile } \\
\text { marketing within the global context. }\end{array}$ & 22 & 26 & 21 & 28 & 5 & 178 \\
\hline Lamberton and Stephen (2016) & $\begin{array}{l}\text { Digital Social Media as a facilitator of individual expression, a decision support } \\
\text { tool, and a source of market intelligence. }\end{array}$ & 2 & 20 & 42 & 77 & 33 & 174 \\
\hline Scharl, Dickinger, and Murphy (2005) & $\begin{array}{l}\text { Message and media characteristics influence in three dependent measures of success: } \\
\text { consumer attention, consumer intention and consumer behavior. }\end{array}$ & 15 & 13 & 12 & 14 & 7 & 164 \\
\hline $\begin{array}{l}\text { Bellman, Potter, Treleaven-Hassard, Robinson, } \\
\text { and Varan (2011) }\end{array}$ & $\begin{array}{l}\text { The positive and persuasive impact of apps in increasing interest in the brand and the } \\
\text { brand's product category. Apps with an informational/user-centered style are more } \\
\text { effective in altering purchase intention. }\end{array}$ & 22 & 19 & 24 & 29 & 16 & 137 \\
\hline Kaplan (2012) & $\begin{array}{l}\text { What mobile social media is, what it is not, and how it differs from other types of } \\
\text { mobile marketing applications. How firms can make use of mobile social media } \\
\text { for marketing research, communication, sales promotions/discounts, and relationship } \\
\text { development/loyalty programs. }\end{array}$ & 24 & 27 & 22 & 12 & 12 & 135 \\
\hline Zhang and Mao (2008) & $\begin{array}{l}\text { Predicted the intention to use two key determinants of TAM, the perceived usefulness } \\
\text { and perceived ease of use of SMS advertising messages. Trust in SMS } \\
\text { advertising and subjective norms also contributed to the intention to use. }\end{array}$ & 7 & 10 & 5 & 10 & 6 & 127 \\
\hline Varnali and Toker (2010) & $\begin{array}{l}\text { Classifies the literature on mobile marketing and assesses the-state-of-the-art in order } \\
\text { to facilitate future research. }\end{array}$ & 10 & 12 & 11 & 11 & 5 & 109 \\
\hline Winer (2009) & $\begin{array}{l}\text { The kinds of new media that companies are using to engage customers and the } \\
\text { challenges that these media present from the perspective of the marketing manager. }\end{array}$ & 12 & 15 & 8 & 9 & 8 & 103 \\
\hline Fong, Fang, and Luo (2015) & $\begin{array}{l}\text { Competitive locational targeting produced increasing returns for deep promotional } \\
\text { discounts, whereas targeting the focal location produced decreasing returns for } \\
\text { deep discounts. }\end{array}$ & 10 & 22 & 21 & 31 & 8 & 93 \\
\hline
\end{tabular}

Source: Prepared by the authors. 
Seminal theories examining the acceptance of new technologies such as the Diffusion of Innovation Theory (Rogers, 1983), the Technology Acceptance Model - TAM (Davis, 1989), and the Unified Theory of Acceptance and Use of Technology - UTAUT (Venkatesh et al., 2003) are the core of the majority of mobile shopping studies ( San-Martín et al., 2016; Gupta \& Arora, 2017; Hubert et al., 2017). The most cited studies are presented in Table 1. Some of these studies suggest factors that enhance the adoption of mobile shopping (Shankar et al., 2010; Zhang \& Mao, 2008) by either having a positive effect or functioning as key mediating mechanisms, whereas others are focused on factors that curtail technology adoption, such as perceived risks and, most importantly, they present the mobile marketing effect on the customer decision-making process (Bellman et al., 2011; Fong et al., 2015). We should also note that the intrinsic characteristics of customers may affect the intention to adopt mobile shopping (e.g. Patsiotis et al., 2020). Young and social media savvy participants who generally have a strong interest in shopping are usually networked shoppers (Pantano \& Gandini, 2018). Customers who feel overwhelmed by technology and are skeptical about its correct functioning are inhibited from adopting new technologies (Parasuraman \& Colby, 2015), while customers who have a positive view of technology (Gupta \& Arora, 2017; Parasuraman \& Colby, 2015), such as tech pioneers and influential leaders, are usually motivated to adopt technology innovations.

Mobile use is supported by customer innovation and personal attachment to mobile technologies (Pantano \& Priporas, 2016). Mobile trust influences customer intentions to engage in mobile shopping (Giovannini et al., 2015). Trust in online commerce plays an important part in trust in mobile commerce. Online trust involves technology and also the entity deploying it (Boyd, 2003). The customer's perception of a lack of physical contact - the "dehumanizing effect" (Parasuraman \& Colby, 2015, p. 62) - is still ambiguous, and is a driver for some and as an inhibitor for others (Chaparro-Peláez et al., 2016; Parasuraman \& Colby, 2015).

Gupta and Arora (2017) have introduced new lenses to examine mobile shopping using behavioral reasoning theory, analyzing "reasons for" and "reasons against". Customers undertake cost-benefit tradeoffs in purchasing decisions. Before that, Maity and Dass (2014) also applied behavioral reasoning theory, together with media richness theory, in order to investigate the impact of media richness on customer channel choice in terms of the in-store, ecommerce, or m-commerce shopping. Customers would rather adopt the mobile channel for shopping in simpler decision-making tasks, due to low media richness (Maity \& Dass, 2014). Mobile shopping is prevalent in low-consideration contexts. It is not suitable for higher involvement categories, at least not as a primary touchpoint (Wang et al., 2015). 


\section{Mobile promotion strategies: push notifications}

Advances in mobile technologies are affecting customer purchase behavior, particularly in an array of pull and push promotion strategies. According to Molitor et al., (2015), mobile pull differs from mobile push in three distinct ways: i) user perception, ii) interaction with coupons/ads, and iii) interface design. In general, pull notifications make use of wi-fi and cell tower mobile technology; are delivered via app, mobile internet, or mobile barcode; are associated with a planned purchase customer mindset and have a prolonged redemption window. Pull notifications, on the other hand, make use of tower triangulation, wi-fi, geo-fence, and beacon technology; are delivered via SMS, text, or app; are associated with an impulse purchase customer mindset and have an immediate redemption window (Andrews et al., 2016). Mobile pull tends to be less often considered as spam and less privacy intrusive, giving users more control over their interactions with the provider, since it refers to users actively searching for a product or a service.

Tang et al. (2016) applied an innovative approach to the adoption of mobile purchases when analyzing this phenomenon from the perspective of channel migration using the pushpull-mooring (PPM) theory. Based on human migration studies, this theory suggests that there are negative factors at migrants' point of origin that push people, while positive factors at destinations attract people and mooring factors facilitate or inhibit their decisions to migrate. The Tang et al.'s (2016) model tests the inconvenience of traditional internet channels and the perception of high prices as factors of pressure; the perceived utility and perceived ease of use of mobile shopping as attractive factors, and high costs of change and low security/privacy as mooring factors in the background analysis that influence customers in their decisions to migrate from online shopping (based on PCs) to mobile purchases. The cost of change was not significant in the results, but safety was in line with other studies in terms of the acceptance of mobile technology (Hubert et al., 2017; San-Martín et al., 2016).

Researchers have consistently reported that there is a relationship between mobile marketing and individual responses regarding last-click behavior. However, the interest in investigating how interaction via mobile technology drives store visits has recently become a topic of debate (Table 2). 
Table 2 - Research on mobile marketing and offline purchase behavior, promotion strategies, and geolocation promotions

\begin{tabular}{|c|c|c|}
\hline & Investigation & Authors \\
\hline 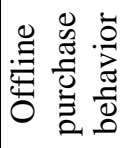 & $\begin{array}{l}\text { How mobile technologies affect purchase behavior } \\
\text { in retail brick-and-mortar stores. }\end{array}$ & $\begin{array}{l}\text { Andrews et al. (2016), Groß (2015), } \\
\text { Bakopoulos et al. (2017), Shankar et al. (2016) }\end{array}$ \\
\hline 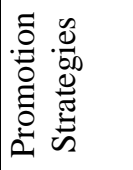 & Mobile pull and push promotions in retail settings. & $\begin{array}{l}\text { Beeck and Toporowski (2017), } \\
\text { Fong et al. (2015), Tang et al. (2016) }\end{array}$ \\
\hline 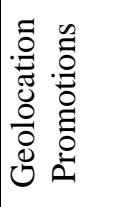 & Mobile targeting (location-based) promotions. & $\begin{array}{l}\text { Verhoef et al. (2017), Grewal et al. (2018), } \\
\text { Ieva et al. (2018), Pantano and Gandini (2018), } \\
\text { Fulgoni and Lipsman (2016), Grewal et al. (2016), } \\
\text { Hui et al. (2013), Tong et al. (2020), Ghose et al. } \\
\text { 2019) }\end{array}$ \\
\hline
\end{tabular}

Source: Prepared by the authors.

Figure 1 presents cluster analysis of the authors connected by VoSviewer. We chose the Web of Science's Social Sciences Citation Index (SSCI) as a database and defined our criteria for searching the articles. Our search was restricted by topic (title, keywords, or abstract) using the keywords 'Location-Based Marketing' or 'Mobile Marketing' and its derivatives, from 1979 to 2020. But it is only from 2004 on that the Mobile Marketing research field actually has citations. Next, we performed cluster analysis using the VOSviewer 1.6.13, which makes it possible to make a quantitative analysis of a research area through historical data (authors, citations, co-citations, among others), and also identify the main trends (Bonilla et al., 2015). VOSviewer helps the understanding of bibliometric networks through map visualization.

As shown in Figure 1, the red cluster groups the research related to the acceptance of the mobile channel (Bauer et al., 2005; Scharl et al., 2005; Tsang et al., 2004), but with a focus on mobile campaigns, mainly the acceptance of SMS messages. There is a stronger link of citations between the red and green clusters with the work of Barwise and Strong (2002) exploring the effectiveness of SMS text messaging as an advertising medium for reaching young adults. Unlike prior work, which has mostly investigated mobile marketing focusing on the acceptance of new technologies (the blue cluster) (cf. Davis, 1989; Rogers, 1983; Venkatesh et al., 2003), a recent distinct research stream (green cluster), has mainly focused on important insights on connecting online efforts with offline behavior. These studies assess how targeted mobile promotions can attract additional customers to physical stores and also increase unplanned spending (Hui et al., 2013). 
Push notifications offer a convenient way to stimulate unplanned purchases by reaching customers when they are close to a store, point-of-purchase, or considering a purchase (Andrews et al., 2016, p. 16). These notifications can be highly effective, but the actual location of individuals has an important effect on how they respond to this strategy. In addition, the inappropriate use of technology may deter potential customers instead of attracting them (Beeck \& Toporowski, 2017). Beeck and Toporowski (2017) have provided evidence of the potential risks and benefits of sending mobile messages to customers, as part of a digitalization strategy

Figure 1 - Mobile marketing research

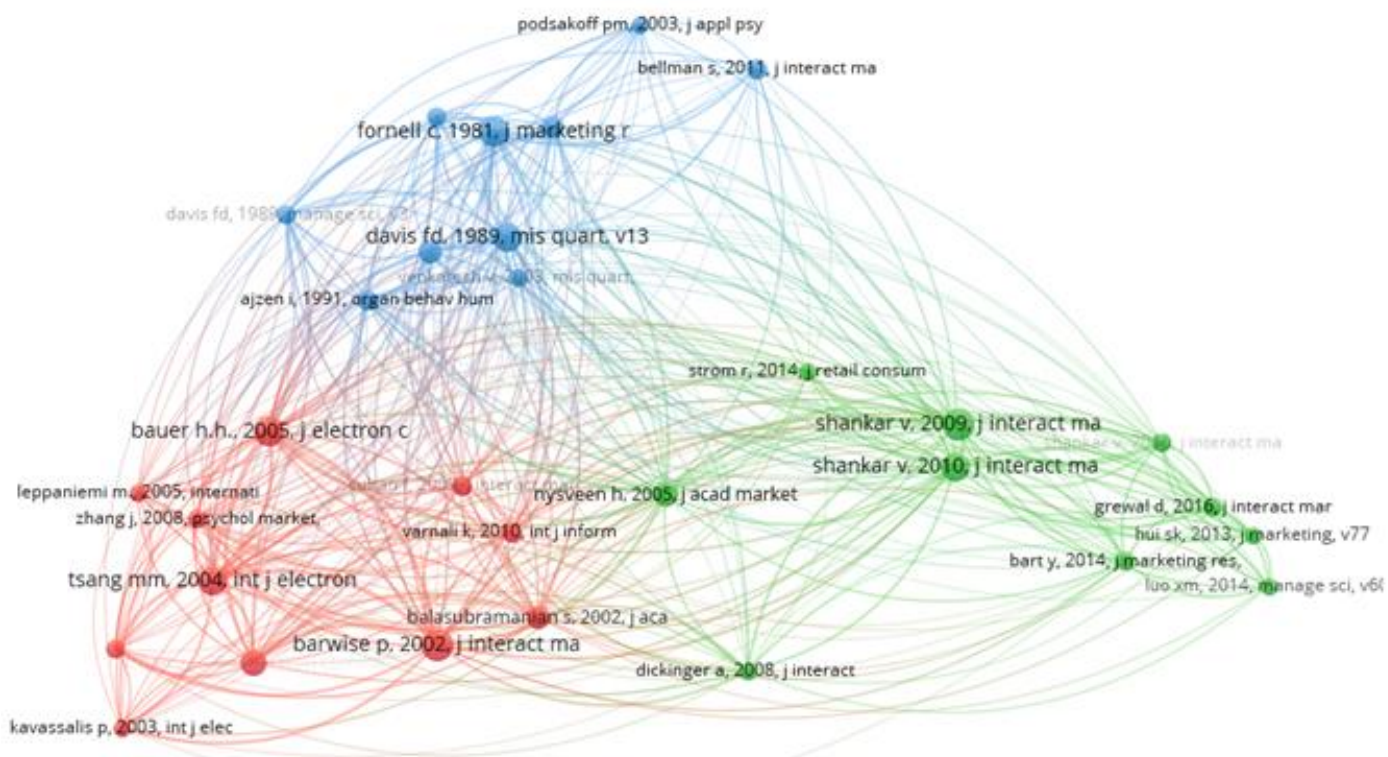

Source: VosViewer - bibliometric coupling.

for brick-and-mortar enterprises using new technologies. According to Beeck and Toporowski (2017), mobile targeting is influenced by the content of the mobile message and the customer's location upon receiving the message. This leads us to link mobile pull and push promotions with geolocation strategies.

\section{Mobile marketing and geolocation promotions}

Location-based marketing (LBM), or actions based on geolocation or geofencing represent one of the most fertile fields for Mobile Marketing. The locational targeting of customers within certain designated areas (typically near a firm's location) is referred to as geofencing (the activation perimeter). The ability to support location-based applications is a 
unique feature of mobile devices (Grewal et al., 2016). Geobehavioral marketing refers to the ability to target unique audiences and/or users based on the context of a given location or past or present location behavior (MMA, 2019). Mobile technologies empower researchers and managers in drawing insights regarding marketing phenomena in a way that was impractical to examine in the past, since mobile technologies provide access to the real-time presence of customers (Cliquet, 2021; Fong et al., 2015), together with a number of pieces of data provided by this intimate device.

Digital Marketing encompasses Mobile Marketing, and although these concepts have many similarities, they are not exactly the same (Maity \& Dass, 2014). The mobile construct can cover the device, the technology, the channel, or other aspects. Regarding the device, mobile is any centrally connected portable device that can be used on the move, such as a smartphone or a tablet (Shankar et al., 2016). Despite their similarities, the online and mobile channels provide different experiences to the customer. Both have in common the separation of the moment of purchase from the moment of collection/consumption, eliminating the traditional time and space barriers of physical retail (Pantano \& Priporas, 2016). It is anytime, anywhere shopping. However, smartphone shopping allows customers to shop when they are on the go, with no time or space constraints (Tang et al., 2016), while e-commerce requires an area for the PC or notebook, which may impose certain time and location restrictions.

The mobile channel's most important quality is the uniqueness of the functionalities that mobile devices offer, particularly geolocation (Cliquet, 2021). Using the customer's location for purchases, allows you to enter the context of the process: the right product, for the right person, at the right time, is just what the mobile channel provides due to its ubiquitous nature. The mobile channel allows a company to approach the customer in various situations and points of contact, linking the offer to the consumption context. Besides, a mobile promotion is less obtrusive because mobile notifications are easy to check with a glance or ignore if so desired (Fong et al., 2015, p. 728).

Locational targeting has been widely adopted by mobile marketers, with Ad Networks already providing media inventory based on geofencing. Geolocation actions are mainly aimed at boosting unscheduled buying behavior since they usually occur close to the point of sale. There is also competitive locational targeting, the practice of making promotions to customers near a competitor's location, using mobile geolocation promotions as competitive weapons (Fong et al., 2015). The effectiveness of mobile promotions is guided by the principle of context - taking the right action at the right place and time (Verhoef et al., 2017). As Fong et al. (2015, 
p. 726) put it, mobile promotions can now reach customers when and where they are most receptive. The difference between an ad being perceived as an interruption or as a welcome hello is often timing. In these cases, both the location and timing of the message are crucial, and the challenge is to target "moments of relevance" during the customer's journey (Bakopoulos et al., 2017). 
Table 3 - Prior geolocation mobile studies

\begin{tabular}{|c|c|c|c|c|c|c|}
\hline Authors & & Method & Independent Variables & $\begin{array}{l}\text { Dependent } \\
\text { Variables }\end{array}$ & Setting & Main Conclusions \\
\hline Hui et al, 2013 & Paper coupon & Field Experiment & $\begin{array}{l}\text { In-store path length, impulsivity, } \\
\text { shopping budget and } \\
\text { demographics. }\end{array}$ & $\begin{array}{l}\text { Unplanned } \\
\text { expenditure }\end{array}$ & $\begin{array}{l}\text { Mobile promotion coupons. Participants agreed } \\
\text { to use a PathTracker belt, embedded with } \\
\text { an RFID tag. }\end{array}$ & $\begin{array}{l}\text { Offline effects (i.e., travel distance in stores) of } \\
\text { coupons delivered in online (mobile) formats on in- } \\
\text { store spending. }\end{array}$ \\
\hline Luo et al, 2014 & Push (SMS) & Field Experiment & $\begin{array}{l}\text { Temporal and geographical } \\
\text { distance }\end{array}$ & $\begin{array}{l}\text { Response to } \\
\text { discounted movie } \\
\text { tickets }\end{array}$ & $\begin{array}{l}\text { Promoted in cooperation with IMAX Theaters. } \\
\text { The wireless provider sent SMS messages } \\
\text { promoting discounted tickets. Recipients } \\
\text { purchased movie tickets by downloading the } \\
\text { accompanying movie ticket application. }\end{array}$ & $\begin{array}{l}\text { In terms of short distances to cinemas, redemption } \\
\text { likelihood is highest if the coupons are sent on the } \\
\text { same day. For longer distances, a promotional lead } \\
\text { time of one day leads to the highest redemption } \\
\text { likelihood }\end{array}$ \\
\hline Danaher et al, 2015 & Push (SMS) & $\begin{array}{l}\text { Panel /Observational } \\
\text { data }\end{array}$ & $\begin{array}{l}\text { Coupon characteristics and } \\
\text { location-based covariates }\end{array}$ & $\begin{array}{l}\text { Consumer } \\
\text { response to } \\
\text { coupon }\end{array}$ & $\begin{array}{l}\text { Mobile coupons sent out to mall visitors by a } \\
\text { third party. }\end{array}$ & $\begin{array}{l}\text { Location and time of delivery significantly } \\
\text { influence redemption }\end{array}$ \\
\hline $\begin{array}{l}\text { Fong, Fang and Luo, } \\
2015\end{array}$ & Push (SMS) & $\begin{array}{l}\text { Randomized field } \\
\text { experiment }\end{array}$ & $\begin{array}{l}\text { Competitive locational targeting } \\
\text { and discount sizes }(20,40,60 \%) \\
\text { - geo-conquesting }\end{array}$ & Purchase rate & $\begin{array}{l}\text { Promotional offers were sent to mobile users } \\
\text { located near a focal retailer's own location, a } \\
\text { competitor's location, and a benchmark location }\end{array}$ & $\begin{array}{l}\text { Large discounts were } \\
\text { optimal for the competitive location, whereas } \\
\text { medium discounts were optimal for the focal } \\
\text { location. Overall redemption rate of } 2.5 \% \text { for all of } \\
\text { the treatment combinations }\end{array}$ \\
\hline Molitor et al, 2016 & Pull & $\begin{array}{l}\text { Large-scale } \\
\text { randomized field } \\
\text { experiment }\end{array}$ & $\begin{array}{l}\text { Providing distance information } \\
\text { and a distance-based ranking } \\
\text { mechanism (display rank) }\end{array}$ & $\begin{array}{l}\text { Clicks on coupons } \\
\text { (click as a positive } \\
\text { response) }\end{array}$ & $\begin{array}{l}\text { Mobile coupon aggregator, consisting of } 3,152 \\
\text { different stores in } 2,589 \text { cities in Germany, for } \\
13 \text { product categories. }\end{array}$ & $\begin{array}{l}\text { The most effective coupon interface design is based } \\
\text { on offers that are sorted by distance; increased } \\
\text { distance decreases the likelihood of coupons being } \\
\text { chosen. The trade-off between discount and } \\
\text { geographical distance is therefore } 148 \text { meters per } \\
\text { percentage point of discount. }\end{array}$ \\
\hline $\begin{array}{l}\text { Dubé, Fang, Fong, } \\
\text { \& Luo, } 2017\end{array}$ & Push (SMS) & Field Experiment & $\begin{array}{l}\text { Random prices of competing } \\
\text { movie theaters, consumer } \\
\text { locations }\end{array}$ & Ticket purchase & $\begin{array}{l}\text { A mobile SMS promotion consisted of an offer } \\
\text { to buy one voucher for any } 2 \mathrm{D} \text { movie showing at } \\
\text { a given movie theater on the day the SMS } \\
\text { message was sent. }\end{array}$ & $\begin{array}{l}\text { Geoconquesting study. Findings demonstrate the } \\
\text { importance of considering competitor responses } \\
\text { when piloting novel price-targeting }\end{array}$ \\
\hline $\begin{array}{l}\text { Beeck and } \\
\text { Toporowski, } 2017\end{array}$ & Pull & $\begin{array}{l}\text { Online based } \\
\text { experiment }\end{array}$ & $\begin{array}{l}\text { Location (home, city, shop) and } \\
\text { content (coupon, promotional } \\
\text { message) }\end{array}$ & $\begin{array}{l}\text { Intention to } \\
\text { redeem }\end{array}$ & Discount Shopping App & Low usage rate for discount mobile applications. \\
\hline $\begin{array}{l}\text { Ghose, Li, \& Liu, } \\
2019\end{array}$ & SMS coupons & $\begin{array}{l}\text { Large-scale } \\
\text { randomized field } \\
\text { experiment }\end{array}$ & $\begin{array}{l}\text { No ads; ads from randomly } \\
\text { selected stores; ads based on } \\
\text { current location information; ads } \\
\text { based on trajectory information. }\end{array}$ & $\begin{array}{l}\text { Coupon } \\
\text { redemption }\end{array}$ & Shopping mall with more than 300 stores. & $\begin{array}{l}\text { Trajectory-based mobile targeting can lead to higher } \\
\text { redemption probability, faster redemption behavior, } \\
\text { and larger transaction amounts. }\end{array}$ \\
\hline $\begin{array}{l}\text { Högberg, Wästlund, } \\
\text { Aas, Hjemdahl, \& } \\
\text { Nordgård, } 2020\end{array}$ & Push notification & Field Experiment & $\begin{array}{l}\text { Labelling participants with an } \\
\text { appropriate trait vs a neutral ad }\end{array}$ & $\begin{array}{l}\text { Geographical data } \\
\text { using iBeacon } \\
\text { (visit to the } \\
\text { location) }\end{array}$ & $\begin{array}{l}\text { Mobile messages sent to visitors living in a } \\
\text { limited area near Dyreparken Park (Norway). }\end{array}$ & $\begin{array}{l}\text { The label had a positive and significant effect on } \\
\text { moving visitors to the targeted location. }\end{array}$ \\
\hline
\end{tabular}


Recent research has shown location-based marketing's positive effect on users' attitudinal and behavioral responses such as the intention to redeem (Beeck \& Toporowski, 2017), purchase rate (Fong et al., 2015), and clicks on coupons (Molitor et al., 2015). Table 3, to the best of the authors' knowledge, presents all the studies that have empirically investigated location-based marketing so far. However, future research is still needed, especially in terms of field experiments with real and potential customers in order to better explain and further current mobile location-based marketing research.

Although some of the presented studies have adopted a field experiment methodology (Dubé et al.2017; Hui et al., 2013; Luo et al., 2014), they have been mainly focused on individual responses to push notifications that offer coupon discounts. Nevertheless, it is worthwhile to point out that product type, consumer characteristics, time, and location of the message received may also influence mobile coupon redemption rates (Beeck \& Toporowski, 2017). There is a range of technologies that can be used for location tracking, such as Wi-Fi, RFID, GPS, or beacons. The use of these technologies is still a challenge for experimental research, but it is also a future trend. Individual resistance and resource availability are some of the barriers that need to be overcome. Beacons, for instance, rely on enabling smartphone Bluetooth. Since it drains a smartphone's battery, only a small percentage of users keep it on.

As for GPS, the data accuracy depends on signal reception and these searches also drain batteries. In addition, it is essential not to breach privacy policies within General Data Protection Regulation. For instance, research cannot be related to categories such as hospitals or churches. Possible behavioral criteria should include visits to a category of places, such as restaurants (in general), gyms, offline location behavior, installed apps (consider that children may install apps in parent's devices or type of mobile device and mobile operator. According to Bakopoulos et al. (2017, p. 450), marketers have two goals: strengthen consideration for the brand by reinforcing image perceptions (the upper part of the purchase funnel) and drive sales (the lower funnel). Therefore, we can aim at measuring attitudinal consideration (the upper funnel) or actual behavior (the lower funnel) to identify customers at the right moment and use media to trigger immediate responses and drive acquisition. That is, we have a choice of attitudinal survey-based metrics (considerations) and/or actual behavioral metrics.

Reaching customers at the right place and at the right time should result in higher response rates. Moreover, properly timed promotions to customers in targeted locations should produce a positive incremental effect compared to non-targeted or asynchronous promotions (Fong et al., 2015; Molitor et al., 2015). In sum, previous research data supports the prediction 
that the proximity of physical locations and the content of mobile messages are important aspects of mobile marketing strategies in $\mathrm{O} 2 \mathrm{O}$ efforts. From this perspective, interacting with a message via mobile technology needs to be relevant to the customer context. Drawing on research on mobile marketing and offline purchase behavior, promotion strategies, and geolocation promotions, we will next summarize the findings and present a research agenda focused on location-based push notifications and a) visits to stores, b) coupon offers, c) personalized content and d) high engagement content (Figure 2). Unlike prior work, which has mostly considered online-to-online responses, we summarize the findings that may stimulate additional work in light of other arguments in this nascent field. Our effort is focused on discussing how to deliver more effective mobile message content based on geolocation data in order to drive store visits and to connect online efforts to offline behavior.

Figure 2 - Research agenda: marketing and geolocation

\begin{tabular}{|c|c|c|}
\hline $\begin{array}{l}\text { Distance from } \\
\text { the target store }\end{array}$ & & $\begin{array}{c}\text { Coupons } \\
\text { offer }\end{array}$ \\
\hline $\begin{array}{c}\text { Planning the timing and location of } \\
\text { marketing messages can lead } \\
\text { to a more efficient } \\
\text { outcome }\end{array}$ & \multirow{2}{*}{$\begin{array}{c}\text { Mobile } \\
\text { location-based } \\
\text { marketing } \\
\text { and offline } \\
\text { behavior }\end{array}$} & \multirow[t]{2}{*}{$\begin{array}{c}\text { If the goal is conversion, a message } \\
\text { that promotes customer action } \\
\text { shall be pursued }\end{array}$} \\
\hline $\begin{array}{c}\text { Personalized } \\
\text { content }\end{array}$ & & \\
\hline $\begin{array}{l}\text { Higher benefits perception when } \\
\text { the offer comes in the form } \\
\text { of personalized messages based } \\
\text { on user-selected preferences }\end{array}$ & & $\begin{array}{l}\text { Fun and enjoyable content that } \\
\text { facilitate the opportunity for } \\
\text { interactivity }\end{array}$ \\
\hline
\end{tabular}

Source: Prepared by the authors.

\subsection{Location-based push notifications and visits to stores}

Locations and other data signals allow companies to target key segments of customers who are much more likely to respond positively to promotional offers (Bakopoulos et al., 2017). Behavioral targeting and contextual targeting justify their incremental cost and improve the performance of campaign results: providing more consideration, more sales, and greater dollar expenditure (Bakopoulos et al., 2017). Contextual targeting refers to identifying customers who are browsing relevant content about a given category on their mobile devices. 
However, geolocation actions are mainly aimed at boosting unscheduled buying behavior (Hui et al., 2013), since this usually occurs close to the point of sale.

When you know where customers are and how they behave, you can not only customize offers, you can also offer rewards and a personalized experience. The results of Grewal et al. (2018, p. 102) indicate that mobile phone use in-store can increase purchases overall because customers "deviate from their conventional shopping loop". In a previous Walmart study, activation by location had a higher impact on store visitation than the activation of past shoppers (Bakopoulos et al., 2017).

Thus, the location-based approach reveals an opportunity to enhance the customer experience in the physical store and the online-offline integration of the brand. "Proximity location targeting, when matched with expandable mobile display units, also improves the impact of advertising in terms of driving foot traffic" (Bakopoulos et al., 2017, p. 450). Planning the timing and location of marketing messages can lead to a more efficient outcome. Molitor et al. (2015) analyze whether mobile promotions that are triggered by geofences (i.e., sent when a customer enters a pre-defined area around the promoting store) are more effective compared with those received without geofences. This leads to the first proposition.

Proposition 1: Location-based push notifications when sent to a location near the target store increase the number of visits to offline points of sale.

\subsection{Location-based push notifications and coupon offers}

In functional terms, location-based coupons can be either pushed to users (i.e., mobile push) or provided on demand via specific applications in which users can intentionally browse through available coupons (i.e., mobile pull) (Xu et al., 2009). Basically, mobile pull and push offers vary in their delivery mechanisms. In a pull scenario, users are explicitly searching and asking for these offers (Molitor et al., 2015). When they are in a push scenario, users are not explicitly asking for these offers; these offers are automatically pushed out to them (based on a variety of targeting criteria).

Previous studies have demonstrated that the distance to the point of sale affects the likelihood of purchase (Molitor et al., 2015), especially if there is some type of coupon involved. Research shows that there is greater redemption of coupons when they are sent to mobile devices (Hui et al., 2013; Klabjan \& Pei, 2011). The reason that distance may matter more in terms of mobile devices (compared with PCs) is that mobile coupon applications are 
used as a ubiquitous information medium with the intention of bringing customers (back) to physical retail stores (Molitor et al., 2015).

If the purpose of the campaign is branding, the fact that the user is exposed to the brand via institutional communication is relevant. Achieving viewability and, perhaps, engagement should be sufficient. "A mobile approach is particularly effective for established brands, which customers have less need to research or validate" (Bakopoulos et al., 2017, p. 449). However, if the goal is converting the customer, a message that promotes customer action shall be pursued. In fact, Shankar et al. (2016) stress that unexpected promotions increase the sense of serendipity in the mobile process, which helps increase customer engagement.

However, the perceived value of a location-based coupon may depend on the actual geographic location where users open and access their mobile coupon app (Molitor et al., 2015). According to Fong et al. (2015), it is shortsighted to conclude that locational responsiveness to mobile promotions is merely a function of proximity to a retailer's own stores. For instance, Fong et al. (2015) analyzed the effects of the size of discounts on competitive locations, with the cooperation of a mobile service provider. They reached the conclusion that large discounts were optimal for the competitive location, whereas medium discounts were optimal for the focal location. The results of Beeck and Toporowski (2017) indicate that mobile messages can be highly effective for users of discount apps when the customer is near the shop.

Proposition 2: Visits to offline points of sale generated by location-based mobile notifications occur more often when the content is promotional than when the content is institutional.

\subsection{Location-based push notifications and personalized content}

A keyword in mobile promotion is permission. "Real-time location information is potentially quite sensitive, and customers may not always understand the lengthy terms and conditions they have agreed to" (Verhoef et al., 2017, p. 7). Technology such as beacons, with the customers' permission, enables retailers to go beyond targeting. Retailers have the opportunity to collect data, measure real-time shopping behavior, and customize promotions (Beeck \& Toporowski, 2017). Mobile beacons are an entirely different marketing communication tool from mobile messaging, in that it requires a customer to install the app. But, once installed, a customer's use of mobile technology generates information that can be captured by firms for targeting purposes (Verhoef et al., 2017). The process of mobile activation is extremely delicate and therefore must be very well planned. 
Because of the geolocation effect on boosting unscheduled buying behavior, these impulse purchases may generate buyer's remorse. To minimize this negative effect, push notifications should in fact contain a benefit that adds value to the customer, preferably a customized one (Tong et al., 2020). There is a common perception that better-targeted ads necessarily require access to a customer's personal data, with improved targeting techniques being advantageous to firms (Kim et al., 2019). Well-targeted ads are objectively more personalized; thus, they should by definition be more relevant and interesting to customers (Kim et al., 2019, p. 908). Targeting an ad based on customer behavior can increase the personproduct fit, and consequently, the ad's effectiveness.

Theories of self-disclosure suggest that customer willingness to disclose personal information is based on the customer's assessment of costs and benefits (Andrade et al., 2002, p. 350). We can draw a parallel with push notification opt-ins: for customers to disclose their location to companies, they need to assess the costs and benefits offered. Another benefit of mobile technology is its unique services, mainly related to the possibility of offers based on real-time location (Faqih \& Jaradat, 2015; Gupta \& Arora, 2017). These offers come in the form of personalized messages based on user-selected preferences, requiring less effort to find information (Eastin et al., 2016). Systems can adapt their behavior to individual use, automatically recognizing forms of customer information (Pantano \& Priporas, 2016).

Proposition 3: Visits to offline points of sale generated by location-based mobile notifications occur more often when the content is personalized.

\subsection{Location-based push notifications and high engagement content}

Despite the increase in mobile retailing, customers still experience anxiety and a lack of trust in the use of m-commerce (Gupta \& Arora, 2017). Thus, mobile shopping tasks should be easy (user-friendly with simple transaction processes) and cost-effective to attract customers (Tang et al., 2016). Moreover, they should be fun and enjoyable. Perceived entertainment is really important in m-commerce, and it may provide a better explanation for technology adoption than utilitarian motivations, such as perceived utility (van der Heijden, 2004). However, because screens are smaller, media richness is affected in mobile communication (Pantano \& Priporas, 2016). Media richness is related to the ability to communicate information to the customer through text, audio, video, and face-to-face messages (Maity \& Dass, 2014). Moreover, the lack of user-friendly interfaces on smaller screens can turn into discomfort and 
inconvenience. This space limitation (small keyboards and small screens) may make interaction via mobile mentally and physically exhausting, and thus cognitively onerous (Sohn et al., 2017).

Media richness is defined as the degree to which a medium can facilitate shared meaning (Daft et al., 1987). Previous studies have extended media richness theory to explain media's ability to express rich information by using the four aspects of media richness (Tseng et al., 2017): immediate feedback; multiple cues; personal focus; and a variety of language. Immediate feedback refers to the ability to provide rapid bidirectional communication and rapid response messages. Multiples cues refer to text and icons whether personal focus makes reference to emotions. Finally, a variety of language involves a large pool of symbols (Tseng et al., 2019). The use of game design elements is one of the strategies which is useful in enhancing non-game goods and services by increasing customer value and encouraging valuecreating behaviors such as engagement (Hofacker et al., 2016). In fact, entertainment in mobile shopping is important to achieve satisfaction and positive word-of-mouth (San-Martín et al., 2016). To be fun and enjoyable, the m-site's design "should facilitate the opportunity for interactivity between the customer and the company, or between several customers" and give the option of viewing and interacting better with images (San-Martín et al., 2016, p. 609).

As has been pointed out, customizing or targeting advertisements becomes more critical on a smartphone because of space limitations (Molitor et al., 2015). In fact, Hofacker et al. (2016) have suggested that the use of game design elements executed on a mobile platform has the potential to affect customer entertainment and also can contribute to in-store engagement. Similarly, Scholz and Smith (2016) have observed how augmented reality can help marketers optimize their campaigns and enhance various types of consumer engagement such as userbrand engagement, user-user engagement, and user-bystander engagement. That being so, we offer the following proposition:

Proposition 4: Visits to an offline point of sale generated by location-based mobile notifications occur more often with high engagement content.

\section{Research agenda}

Mobile shopping is a digital paradigm shift in retail, a key tool to enhance the consumer experience in physical stores. Customers navigate between online and offline channels, but most interactions end up in a physical environment. More than half of web browsing takes place via mobile devices and 65\% of Google searches are done through these devices (Statista, 2019). However, the majority of retail sales still occur in brick-and-mortar stores (85\%, according to 
a 2019 report from Statista). The customers pass through multiple channels and points of contact, with the mobile channel being the hub of this process. Thus, the approach should be increasingly multimedia and cross-platform, taking advantage of the synergies that the mobile channel offers in relation to other channels. In a scenario where most of our digital minutes happen on mobile platforms, it is a matter of survival to have mobile-focused planning that embraces the potential of new technologies such as geolocation targeting.

Yet, the real deal behind mobile promotions goes beyond geolocation - it refers to context. Both message content and geolocation are important pillars of context. It is about understanding when, where, and how to talk to consumers, in a way that actually matters to them - so-called relevance. The cell phone is the device that provides the ubiquity this process requires. It represents the "brand in the hand" marketing era (Sultan \& Rohm, 2005). The effectiveness of mobile marketing is guided by the principle of context: taking the right action, in the right place, at the right time.

Mobile shopping is a critical avenue within omnichannel growth, not only in terms of conversion but also in facilitating fulfillment and driving research and consideration, the ideal context for push notifications. There are several practical implications of managing customer offline behavior (visits to offline sites) which engages with digital communication. Unfortunately, there are still few studies of the effects of mobile efforts in terms of offline behavior, from the $\mathrm{O} 2 \mathrm{O}$ perspective (Chiang et al., 2018). Our review of the literature has covered three streams of research: a) how mobile technologies affect customer offline behavior in brick-and-mortar stores (the online to offline relationship); b) main mobile pull and push promotions in retail settings; and c) mobile marketing location-based promotions. The theoretical framework adopted is derived from a critical reflection based on the literature review, which addresses perceptions regarding the factors that would support our presented propositions.

We build on the literature of contextual marketing and behavioral advertising to posit that geolocation mobile promotions directed at customers close to stores increase the chances of positive responses to these promotions. We also posit that this effect is moderated by the type of message, promotional or institutional. The main assumption behind our propositions is that the content and the timing of these messages (considering the customer's geolocation) increase visits to offline sites. Context and convenience thus are the primary drivers of this effect (visits to offline POS generated by mobile notifications), considering that context and convenience are represented by geolocation and message content. That provides the basis for a 
company mobile model that attracts customers to physical locations.

From the managerial point of view, this review contributes to the field by shedding light on mobile activation as part of a retail cross-channel strategy. In addition, it can aid the understanding of how a customer's use of mobile technology can be used to guide customers to in-store purchases and, therefore, improve the allocation of retail media budgets to increase marketing ROI using the mobile channel. Knowing more about motivations for adopting the mobile channel while shopping in multichannel environments, companies can deploy more efficient marketing strategies.

However, although these targeted notifications have the power to enhance brick-andmortar shopping experiences, personalization can backfire, and this is an important issue that deserves future attention within the field. Of particular relevance is that highly personalized notifications can rouse consumer privacy concerns (Aguirre et al., 2016; Kim et al., 2019). Indeed, retailers should be aware of the privacy concerns that inhibit some customers from using mobile stimuli (Beeck \& Toporowski, 2017). Risk avoidance (Pantano \& Priporas, 2016) and a lack of trust play an important role in limiting consumer acceptance of mobile shopping technology and this may extend to consumer willingness to accept targeted push-notifications. This is a managerial challenge in terms of person-level data and bringing one-to-one-marketing campaigns to life.

This review is intended to contribute to mobile marketing, geolocation, behavioral targeting, and omnichannel consumer behavior theory. As Ghose et al. (2015) emphasize, digital tracing of offline customer behavior has become increasingly critical to businesses today in order to understand the inherent preferences of customers in order to improve digital user experiences and business marketing strategies.

Mobile marketing has the power to help brands build personal relationships with customers. However, there is a thin line between making the customer feel special and making them feel stalked, revealing the importance of using the right content at the right time. Retailers should start to adopt a mobile mindset if they wish to perform a successful omnichannel strategy. Hopefully, new research avenues regarding mobile technology will benefit the millions of customers who have yet to experience the benefits of this technology.

Our review of the literature has enabled us to investigate what is known so far about location-based push notifications and how planned strategies related to store visits, coupon offers, personalized content and high engagement content affect customer offline behavior in brick-and-mortar stores (the online to offline relationship). However, to better understand the 
effectiveness of each one of these strategies, empirical tests are needed. By testing them, the demonstration of the expected effects may help direct mobile marketing strategy, driving actions of smaller reach but greater precision, which will thus have higher conversion rates. As mentioned earlier, the precision of mobile actions gains importance in a context where consumers are overwhelmed with advertising. With the huge amount of offers available within the app market featuring the most varied functions and services, consumers lack time and space in their smartphone's memory (storage space) to take advantage of all the services available in app stores. It is a tough task to engage consumers in through an app. They make dozens of downloads, but soon find an app has no relevance and uninstall it. In addition, mobile phones are the most intimate device consumers own, and communication needs to be relevant and convenient to avoid being invasive.

Hopefully, further research will bring insights into the next phase of this exciting mobile phenomena. Yet, the challenge remains of how to transform contextual data into personalized marketing strategies. The "brand in the hand" marketing era has arrived, but we are still scratching the surface of the challenges that it has brought with it. Think mobile.

\section{References}

Aguirre, E., Roggeveen, A. L., Grewal, D., \& Wetzels, M. (2016). The personalizationprivacy paradox: implications for new media. Journal of Consumer Marketing, 33(2), 98110. https://doi.org/10.1108/JCM-06-2015-1458

Andrade, E. B., Kaltcheva, V., \& Weitz, B. (2002). Self-Disclosure on the Web: The Impact of Privacy Policy, Reward, and Company Reputation. Advances in Consumer Research, 29(1), 350-354.

Andrews, M., Goehring, J., Hui, S., Pancras, J., \& Thornswood, L. (2016). Mobile Promotions: A Framework and Research Priorities. Journal of Interactive Marketing, 34, 15-24. https://doi.org/10.1016/j.intmar.2016.03.004

Bakopoulos, V., Baronello, J., \& Briggs, R. (2017). How Brands Can Make Smarter Decisions in Mobile Marketing. Journal of Advertising Research, 57(4), 447-461. https://doi.org/10.2501/JAR-2017-052

Barwise, P., \& Strong, C. (2002). Permission-Based Mobile Background: the Growth of Mobile. Journal of Interactive Marketing, 16(1), 14-24.

Bauer, H. H., Reichardt, T., Barnes, S. J., \& Marcus, M. N. (2005). Driving Consumer Acceptance of Location-Based Services in Mobile Applications: A Theoretical Framework and an Empirical Study. Journal of Electronic Commerce Research, 6(3), 181-192. 
Beeck, I., \& Toporowski, W. (2017). When location and content matter: effects of mobile messages on intention to redeem. International Journal of Retail \& Distribution Management, 45(7/8), 826-843. https://doi.org/10.1108/IJRDM-09-2016-0171

Bellman, S., Potter, R. F., Treleaven-Hassard, S., Robinson, J. A., \& Varan, D. (2011). The Effectiveness of Branded Mobile Phone Apps. Journal of Interactive Marketing, 25(4), 191-200. https://doi.org/10.1016/j.intmar.2011.06.001

Bonilla, C. A., Merigó, J. M., \& Torres-Abad, C. (2015). Economics in Latin America: a bibliometric analysis. Scientometrics, 105(2), 1239-1252. https://doi.org/10.1007/s11192015-1747-7

Chaparro-Peláez, J., Agudo-Peregrina, Á. F., \& Pascual-Miguel, F. J. (2016). Conjoint analysis of drivers and inhibitors of e-commerce adoption. Journal of Business Research, 69(4), 1277-1282. https://doi.org/10.1016/j.jbusres.2015.10.092

Chiang, I.-P., Lin, C.-Y., \& Huang, C.-H. (2018). Measuring The Effects of Online-to-Offline Marketing. Contemporary Management Research, 14(3), 167-190. https://doi.org/10.7903/cmr.18462

Cliquet, G. (2021). From Geomarketing to Spatial Marketing. In S. Colombo (Ed.), Spatial Economics Volume II: Vol. II (pp. 277-305). https://doi.org/10.1007/978-3-030-40094$1 \_10$

Comscore. (2018). Global Digital Future in Focus - 2018 International Edition. Retrieved from https://www.comscore.com/Insights/Presentations-and-Whitepapers/2018/GlobalDigital-Future-in-Focus-2018

Daft, R. L., Lengel, R. H., \& Trevino, L. K. (1987). Message Equivocality, Media Selection, and Manager Performance: Implications for Information Systems. MIS Quarterly, 11(3), 355. https://doi.org/10.2307/248682

Danaher, P. J., Smith, M. S., Ranasinghe, K., \& Danaher, T. S. (2015). Where, When, and how Long: Factors that Influence the Redemption of Mobile Phone Coupons. Journal of Marketing Research, 52(5), 710-725. https://doi.org/10.1509/jmr.13.0341

Davis, F. D. (1989). Perceived Usefulness, Perceived Ease of Use, and User Acceptance of Information Technology. MIS Quarterly, 13(3), 319. https://doi.org/10.2307/249008

Dholakia, U. M., Kahn, B. E., Reeves, R., Rindfleisch, A., Stewart, D., \& Taylor, E. (2010). Consumer Behavior in a Multichannel, Multimedia Retailing Environment. Journal of Interactive Marketing, 24(2), 86-95. https://doi.org/10.1016/j.intmar.2010.02.005

Dubé, J., Fang, Z., Fong, N., \& Luo, X. (2017). Competitive Price Targeting with Smartphone Coupons. Marketing Science, 36(6), 944-975. https://doi.org/10.1287/mksc.2017.1042

Eastin, M. S., Brinson, N. H., Doorey, A., \& Wilcox, G. (2016). Living in a big data world: Predicting mobile commerce activity through privacy concerns. Computers in Human Behavior, 58, 214-220. https://doi.org/10.1016/j.chb.2015.12.050 
eMarketer. (2018). Mobile Trends 201910 Predictions for What Marketers Can Expect. Retrieved from https://www.emarketer.com/content/mobile-trends-2019

Faqih, K. M. S., \& Jaradat, M. I. R. M. (2015). Assessing the moderating effect of gender differences and individualism-collectivism at individual-level on the adoption of mobile commerce technology: TAM3 perspective. Journal of Retailing and Consumer Services, 22, 37-52. https://doi.org/10.1016/j.jretconser.2014.09.006

Fong, N. M., Fang, Z., \& Luo, X. (2015). Geo-Conquesting: Competitive Locational Targeting of Mobile Promotions. Journal of Marketing Research, 52(5), 726-735. https://doi.org/10.1509/jmr.14.0229

Fulgoni, G. M., \& Lipsman, A. (2016). The future of retail is mobile: How mobile marketing dynamics are shaping the future of retail. Journal of Advertising Research, 56(4), 346-351. https://doi.org/10.2501/JAR-2016-041

Ghose, A., Li, B., \& Liu, S. (2015). Digitizing Offline Shopping Behavior Towards Mobile Marketing. International Conference on Information Systems, 1-15.

Ghose, A., Li, B., \& Liu, S. (2019). Mobile Targeting Using Customer Trajectory Patterns. Management Science, 65(11), 5027-5049. https://doi.org/10.1287/mnsc.2018.3188

Giovannini, C. J., Ferreira, J. B., Silva, J. F. da, \& Ferreira, D. B. (2015). The effects of trust transference, mobile attributes and enjoyment on mobile trust. BAR - Brazilian Administration Review, 12(1), 88-108. https://doi.org/10.1590/1807-7692bar2015140052

Grewal, D., Ahlbom, C.-P., Beitelspacher, L., Noble, S. M., \& Nordfält, J. (2018). In-Store Mobile Phone Use and Customer Shopping Behavior: Evidence from the Field. Journal of Marketing, 82(4), 102-126. https://doi.org/10.1509/jm.17.0277

Grewal, D., Bart, Y., Spann, M., \& Zubcsek, P. P. (2016). Mobile Advertising: A Framework and Research Agenda. Journal of Interactive Marketing, 34, 3-14. https://doi.org/10.1016/j.intmar.2016.03.003

Groß, M. (2015). Mobile shopping: a classification framework and literature review. International Journal of Retail \& Distribution Management, 43(3), 221-241. https://doi.org/10.1108/IJRDM-06-2013-0119

Gupta, A., \& Arora, N. (2017). Understanding determinants and barriers of mobile shopping adoption using behavioral reasoning theory. Journal of Retailing and Consumer Services, 36(December 2016), 1-7. https://doi.org/10.1016/j.jretconser.2016.12.012

Gutierrez, A., O’Leary, S., Rana, N. P., Dwivedi, Y. K., \& Calle, T. (2019). Using privacy calculus theory to explore entrepreneurial directions in mobile location-based advertising: Identifying intrusiveness as the critical risk factor. Computers in Human Behavior, 95(September 2018), 295-306. https://doi.org/10.1016/j.chb.2018.09.015

Hofacker, C. F., de Ruyter, K., Lurie, N. H., Manchanda, P., \& Donaldson, J. (2016). Gamification and Mobile Marketing Effectiveness. Journal of Interactive Marketing, 34(2016), 25-36. https://doi.org/10.1016/j.intmar.2016.03.001 
Högberg, J., Wästlund, E., Aas, T. H., Hjemdahl, K., \& Nordgård, D. (2020). Herding the

Hordes: Using Location-Based Services and Mobile Messaging to Affect Visitor Behavior. Journal of Hospitality \& Tourism Research, 44(5), 870-878.

https://doi.org/10.1177/1096348020912449

Hubert, M., Blut, M., Brock, C., Backhaus, C., \& Eberhardt, T. (2017). Acceptance of Smartphone-Based Mobile Shopping: Mobile Benefits, Customer Characteristics, Perceived Risks, and the Impact of Application Context. Psychology \& Marketing, 34(2), 175-194. https://doi.org/10.1002/mar.20982

Hui, S. K., Inman, J. J., Huang, Y., \& Suher, J. (2013). The Effect of In-Store Travel Distance on Unplanned Spending: Applications to Mobile Promotion Strategies. Journal of Marketing, 77(2), 1-16. https://doi.org/10.1509/jm.11.0436

Ieva, M., Ziliani, C., Gázquez-Abad, J. C., \& D’Attoma, I. (2018). Online versus Offline

Promotional Communication. Journal of Advertising Research, 58(3), 338-348. https://doi.org/10.2501/JAR-2017-040

Kim, T., Barasz, K., \& John, L. K. (2019). Why Am I Seeing This Ad? The Effect of Ad Transparency on Ad Effectiveness. Journal of Consumer Research, 45(5), 906-932. https://doi.org/10.1093/jcr/ucy039

Klabjan, D., \& Pei, J. (2011). In-store one-to-one marketing. Journal of Retailing and Consumer Services, 18(1), 64-73. https://doi.org/10.1016/j.jretconser.2010.09.012

Luo, X., Andrews, M., Fang, Z., \& Phang, C. W. (2014). Mobile Targeting. Management Science, 60(7), 1738-1756. https://doi.org/10.1287/mnsc.2013.1836

Maity, M., \& Dass, M. (2014). Consumer decision-making across modern and traditional channels: E-commerce, m-commerce, in-store. Decision Support Systems, 61(1), 34-46. https://doi.org/10.1016/j.dss.2014.01.008

Melumad, S., \& Pham, M. T. (2020). The Smartphone as a Pacifying Technology. Journal of Consumer Research, 0. https://doi.org/10.1093/jcr/ucaa005

MMA. (2019). Location terminology guide: The language of location. Retrieved from http://www.mmaglobal.com/documents/location-terminology-guide\%0A

Molitor, D., Reichhart, P., Spann, M., \& Ghose, A. (2015). Measuring the Effectiveness of Location-Based Pull Advertising: A Randomized Field Experiment. SSRN Electronic Journal. https://doi.org/10.2139/ssrn.2645281

Pantano, E., \& Gandini, A. (2018). Shopping as a "networked experience": an emerging framework in the retail industry. International Journal of Retail and Distribution Management, 46(7), 690-704. https://doi.org/10.1108/IJRDM-01-2018-0024 
Pantano, E., \& Priporas, C.-V. (2016). The effect of mobile retailing on consumers' purchasing experiences: A dynamic perspective. Computers in Human Behavior, 61, 548555. https://doi.org/10.1016/j.chb.2016.03.071

Parasuraman, A., \& Colby, C. L. (2015). An Updated and Streamlined Technology Readiness Index. Journal of Service Research, 18(1), 59-74. https://doi.org/10.1177/1094670514539730

Patsiotis, A., Atik, M., \& Perrea, T. (2020). The influence of m-marketing tools on consumer buying process: evidence from the dining sector. International Journal of Retail \& Distribution Management, 48(10), 1037-1056. https://doi.org/10.1108/IJRDM-06-20180109

PushCrew. (2018). The State of Web Push Notifications. Retrieved from https://medium.com/the-pushcrew-journal/2018s-most-comprehensive-report-on-pushnotification-usage-and-use-cases-dd12a47111b7

Rogers, E. M. (1983). Diffusion of Innovation. New York: The Free Press.

San-Martín, S., Prodanova, J., \& López Catalán, B. (2016). What makes services customers say "buy it with a mobile phone"? Journal of Services Marketing, 30(6), 601-614. https://doi.org/10.1108/JSM-02-2015-0081

Scharl, A., Dickinger, A., \& Murphy, J. (2005). Diffusion and success factors of mobile marketing. Electronic Commerce Research and Applications, 4(2), 159-173. https://doi.org/10.1016/j.elerap.2004.10.006

Shankar, V., Kleijnen, M., Ramanathan, S., Rizley, R., Holland, S., \& Morrissey, S. (2016). Mobile Shopper Marketing: Key Issues, Current Insights, and Future Research Avenues. Journal of Interactive Marketing, 34, 37-48. https://doi.org/10.1016/j.intmar.2016.03.002

Shankar, V., Venkatesh, A., Hofacker, C., \& Naik, P. (2010). Mobile marketing in the retailing environment: Current insights and future research avenues. Journal of Interactive Marketing, 24(2), 111-120. https://doi.org/10.1016/j.intmar.2010.02.006

Sohn, S., Seegebarth, B., \& Moritz, M. (2017). The Impact of Perceived Visual Complexity of Mobile Online Shops on User's Satisfaction. Psychology \& Marketing, 34(2), 195-214. https://doi.org/10.1002/mar.20983

Statista. (2019). E-commerce share of total global retail sales from 2015 to 2023. Retrieved from https://www.statista.com/statistics/534123/e-commerce-share-of-retail-salesworldwide

Sultan, F., \& Rohm, A. (2005). The coming era of "brand in the hand" marketing. MIT Sloan Management Review, 47(1).

Tang, D., Yang, Y., Yan, Y., \& Zhou, M. (2016). What determines online consumers to migrate from PCs to mobile devices? - An empirical approach on consumers' internet cross-channel behaviours. International Journal of Services Technology and Management, 22(1/2), 46. https://doi.org/10.1504/IJSTM.2016.077656 
Tong, S., Luo, X., \& Xu, B. (2020). Personalized mobile marketing strategies. Journal of the Academy of Marketing Science, 48(1), 64-78. https://doi.org/10.1007/s11747-019-00693-3

Tsang, M. M., Ho, S.-C., \& Liang, T.-P. (2004). Consumer Attitudes Toward Mobile Advertising: An Empirical Study. International Journal of Electronic Commerce, 8(3), 6578. https://doi.org/10.1080/10864415.2004.11044301

Tseng, F.-C., Cheng, T. C. E., Li, K., \& Teng, C.-I. (2017). How does media richness contribute to customer loyalty to mobile instant messaging? Internet Research, 27(3), 520 537. https://doi.org/10.1108/IntR-06-2016-0181

Tseng, F., Cheng, T. C. E., Yu, P.-L., Huang, T.-L., \& Teng, C.-I. (2019). Media richness, social presence and loyalty to mobile instant messaging. Industrial Management \& Data Systems, 119(6), 1357-1373. https://doi.org/10.1108/IMDS-09-2018-0415

Van der Heijden. (2004). User Acceptance of Hedonic Information Systems. MIS Quarterly, 28(4), 695. https://doi.org/10.2307/25148660

Venkatesh, Morris, Davis, \& Davis. (2003). User Acceptance of Information Technology: Toward a Unified View. MIS Quarterly, 27(3), 425. https://doi.org/10.2307/30036540

Verhoef, P. C., Stephen, A. T., Kannan, P. K., Luo, X., Abhishek, V., Andrews, M., .. Zhang, Y. (2017). Consumer Connectivity in a Complex, Technology-enabled, and Mobileoriented World with Smart Products. Journal of Interactive Marketing, 40, 1-8. https://doi.org/10.1016/j.intmar.2017.06.001

Wang, R. J.-H., Malthouse, E. C., \& Krishnamurthi, L. (2015). On the Go: How Mobile Shopping Affects Customer Purchase Behavior. Journal of Retailing, 91(2), 217-234. https://doi.org/10.1016/j.jretai.2015.01.002

Xu, H., Teo, H., Tan, B. C. Y., \& Agarwal, R. (2009). The Role of Push-Pull Technology in Privacy Calculus: The Case of Location-Based Services. Journal of Management Information Systems, 26(3), 135-174. https://doi.org/10.2753/MIS0742-1222260305

Zhang, J., \& Mao, E. (2008). Understanding the acceptance of mobile SMS advertising among young Chinese consumers. Psychology and Marketing, 25(8), 787-805. https://doi.org/10.1002/mar.20239 



\title{
NO LUGAR CERTO, NA HORA CERTA: REVISÃO E AGENDA DE PESQUISA SOBRE MOBILE MARKETING COM BASE EM GEOLOCALIZAÇÃO
}

\author{
Annaysa Salvador Muniz Kamiya \\ Doutorado em Administração \\ Centro Universitário FEI \\ São Paulo, SP - Brasil \\ annaysamuniz@gmail.com
}

\author{
Diana Sinclair Pereira Branisso \\ Mestrado em Administração \\ FGV Eaesp \\ São Paulo, SP - Brasil \\ diana.branisso@fgv.br
}

Objetivo: Com base na presença cada vez mais difundida do celular no contexto do varejo, o objetivo da presente pesquisa é examinar os efeitos potenciais do conteúdo da mensagem móvel e dos dados de geolocalização como motivadores de visitas às lojas, conectando os esforços online ao comportamento offline.

Método: Este artigo fornece uma revisão da literatura sobre o que se sabe a respeito dos temas mobile marketing, comunicação baseada em localização e o efeito de notificações push nas atitudes e comportamento dos clientes.

Resultados: Sintetizamos argumentos para notificações push baseadas em localização relacionadas a visitas ao site offline e oferta de cupons, conteúdo personalizado e de alto envolvimento. Com base em várias descobertas de marketing, identificamos um conjunto de proposições.

Contribuições teóricas: Esta revisão pretende contribuir para as teorias de mobile marketing, comportamento do cliente omnicanal e também para a compreensão das promoções baseadas em geolocalização. Ao identificar estratégias que os profissionais de marketing podem empregar para promoções mais eficazes, a presente revisão fornece uma estrutura abrangente para sintetizar as descobertas atuais no marketing baseado em geolocalização e identifica lacunas em nosso conhecimento atual, a fim de estimular o desenvolvimento de pesquisas neste campo.

Implicações gerenciais: A principal suposição que apoia o artigo é a de que o conteúdo e o momento da mensagem (considerando a geolocalização do cliente) aumentam as visitas à loja física. O contexto e a conveniência são apresentados como os principais impulsionadores do efeito (visitas ao ponto de venda físico geradas por notificações móveis), considerando que o contexto e a conveniência são representados pela geolocalização e pelo conteúdo da mensagem. Isso fornece a base para um modelo de estratégias de mobile marketing para que empresas atraiam clientes para locais físicos. A contribuição desta revisão está em iluminar o caminho da ativação mobile na estratégia de crosschannel do varejo.

Palavras-chave: Geolocalização. Marketing com base na localização. Mobile marketing. Varejo. Aquisição de tráfego.

\section{Como citar}

American Psychological Association (APA)

Kamiya, A. S. M., \& Branisso, D. S. P. (2021, abr./jun.). No lugar certo, na hora certa:revisão e agenda de pesquisa sobre mobile marketing com base em geolocalização. Revista Brasileira de Marketing - ReMark 20(2), 203-231. https://doi.org/10.5585/remark.v20i2.18713. 


\section{Introdução}

“Permitir que o Instagram acesse sua localização?”. Essa é uma notificação bastante familiar quando um usuário de smartphone instala um novo aplicativo em seu aparelho. Muitos aplicativos (e.x.: Strava ${ }^{\mathrm{TM}}$, AccuWeather ${ }^{\mathrm{TM}}$, Trip Advisor ${ }^{\mathrm{TM}}$, Facebook ${ }^{\mathrm{TM}}$ ) rastreiam continuamente a localização do usuário em troca do fornecimento de serviços básicos, como determinar a distância percorrida, previsão do tempo local, direções para destinos próximos ou para realizar um check-in em determinado local e compartilhar com amigos. Outros aplicativos, no entanto, não fornecem serviços diretamente relacionados a este rastreio. Em vez disso, eles analisam os dados recuperados do rastreamento de usuários por meio de geolocalização, a fim de projetar estratégias de comunicação muito mais direcionadas, como notificações push. De fato, os smartphones são os dispositivos mais pessoais que os clientes possuem atualmente e, como tal, uma das mais ricas fontes de dados para conversão do varejo (Fulgoni \& Lipsman, 2016). No entanto, a geolocalização em dispositivos móveis é uma tecnologia nova e os estudos sobre seus efeitos nas respostas dos clientes ainda são escassos.

As tecnologias móveis são cada vez mais comuns nos negócios. Em alguns países, como Brasil, Estados Unidos ou Reino Unido, o número de smartphones superou o de notebooks (Comscore, 2018), apresentando uma tendência mundial de uso móvel e assumindo a maior parte da navegação na web. Em alguns países, como China, Estados Unidos, Noruega e Rússia, o digital já se tornou o meio de publicidade dominante em investimento e o canal mais relevante (eMarketer, 2018). Nenhuma inovação tecnológica recente teve um efeito mais transformador na vida dos clientes do que o smartphone, virtualmente indispensável (Melumad \& Pham, 2020).

As notificações push são uma ferramenta importante para o aumento das vendas no varejo via smartphones, pois são uma forma de falar diretamente com o usuário, promovendo produtos ou ofertas e convertendo usuários desconhecidos de aplicativos em clientes conhecidos. No entanto, de acordo com o PushCrew Notifications Report (2018), 39,8\% dos assinantes gostariam de receber notificações mais relevantes e personalizadas. Mais de $74 \%$ do público acha que receber mais de 5 notificações por dia é uma quantidade superior ao tolerável. A maioria das pessoas acredita que os usuários de notificações push deveriam reduzir a frequência de envios, como também enviar notificações personalizadas e relevantes. Além disso, a taxa de cancelamento de recebimento e a frequência das notificações têm uma relação direta. Os cancelamentos de recebimento aumentam quando a frequência aumenta. Isso significa que as notificações push devem ser mais direcionadas e precisas. 
Durante a jornada do cliente, o celular é usado principalmente para educação, informação e engajamento, não necessariamente para o último clique. Pesquisar informações online antes de visitar uma loja desperta certa ansiedade e antecipação, aumentando o desejo pelo produto em questão. No entanto, as empresas ainda lutam para medir efetivamente a influência dos dispositivos móveis nesse processo. Para os profissionais de marketing, ainda é incerto o grau em que os dispositivos móveis geram receita e lucratividade (Bakopoulos et al., 2017). Portanto, ao invés vez de focar apenas no impulsionamento de mais vendas por meio do canal móvel, a presente pesquisa aborda as oportunidades móveis que surgem para aumentar as vendas de modo geral. Ou seja, entender como os dispositivos móveis podem usar notificações push para impulsionar também as vendas em lojas físicas.

Pesquisadores da temática que envolve dispositivos móveis (Pantano \& Priporas, 2016; Beeck \& Toporowski, 2017; Verhoef et al., 2017; Grewal et al., 2018; Gutierrez et al., 2019; Högberg et al., 2020) recomendam estudos adicionais sobre como atribuir atividades online a compras em lojas físicas. Tais estudos indicam a necessidade de investigar sistematicamente o impacto das promoções mobile no comportamento de compra offline. A notificação push com base na localização é uma estratégia particularmente relevante para os varejistas porque permite que atraiam clientes para suas lojas, abordando-os quando eles estão mais receptivos. Assim, compreender o potencial da utilização de tecnologias de geolocalização é uma importante tarefa de pesquisa que pode fornecer contribuições teóricas e práticas.

Embora muito já se saiba sobre vários aspectos do mobile marketing, as estatísticas de compras online geralmente refletem o estágio dos pagamentos feitos pelo canal online, conhecido como métricas de último clique. O efeito das notificações push sobre os indivíduos que visitam a loja ainda não tem recebido muita atenção sistemática, apesar de alguns estudos relevantes terem sido disponibilizados recentemente. Portanto, na primeira metade deste artigo, forneceremos uma visão geral dos estudos apropriados sobre mobile marketing do online para offline (O2O). Na segunda metade, apresentamos um resumo dos estudos apropriados sobre mobile marketing online-para-offline $(\mathrm{O} 2 \mathrm{O})$, que compreende o estado da arte atual na pesquisa sobre notificação push e geolocalização, tomando uma perspectiva $\mathrm{O} 2 \mathrm{O}$ e destacando efeitos contextuais moderadores. Sintetizamos argumentos para notificações push baseadas em localização relacionadas a visitas ao site offline e oferta de cupons, conteúdo personalizado e de alto envolvimento. Além disso, identificamos questões de pesquisa que exigem mais trabalho para garantir o desenvolvimento contínuo e bem-sucedido de pesquisas e práticas de marketing baseadas em geolocalização. Ao identificar estratégias que os profissionais de 
marketing podem empregar para promoções de geolocalização mais eficazes e ao apresentar esse conjunto de proposições, esperamos estimular mais pesquisas empíricas sobre essa estratégia de marketing altamente relevante.

\section{Marketing em dispositivos móveis}

Do final da década de 1990 em diante, as tecnologias avançaram em um ritmo bastante acelerado (Parasuraman \& Colby, 2015), envolvendo mídia social, automação, pagamentos móveis e a ascensão do comércio online. Os clientes adotaram a tecnologia móvel, fazendo uso desses dispositivos para todos os tipos de propósitos: compras, pagamentos, pesquisa e envolvimento com outros clientes. As empresas estão estendendo seu alcance aos clientes por meio do comércio móvel, com a popularidade crescente desse canal de vendas. Compreender os avanços mais recentes em mobile marketing e o que está por vir é essencial para que acadêmicos e profissionais de marketing possam compreender os fundamentos do cliente digital de hoje. O uso do mobile marketing tem aumentado nos últimos anos à medida que o uso e a receptividade do consumidor têm crescido (Fong et al., 2015), mas a substituição do ponto de venda tradicional ainda é irreal (Pantano \& Priporas, 2016). O processo de compra evoluiu para uma realidade que integra o offline e as oportunidades e funcionalidades online. Nesse processo, o celular é o centro do marketing omnicanal, possibilitando uma experiência de cliente conectado (Verhoef et al., 2017). Portanto, há uma necessidade crescente dos varejistas integrarem configurações físicas de varejo com oportunidades e funcionalidades mobile (Pantano \& Priporas, 2016; Beeck \& Toporowski, 2017; Verhoef et al., 2017; Grewal et al., 2018) e torna-se necessário entender melhor como as promoções mobile afetam o comportamento offline do cliente.

De acordo com Pantano e Gandini (2018), o uso intensivo de mídias sociais e tecnologias de comunicação digital surge como parte integrante da experiência de compra dentro e fora da loja. Isso não significa, no entanto, que os varejistas online e offline estejam seguindo caminhos diferentes. Os limites são fluidos, com muitas possibilidades de convergência. Por exemplo, sites ou aplicativos de varejo responsivos podem agilizar a busca do comprador permitindo a retirada da compra na loja (Shankar et al., 2016). Desta forma, a capacidade física operacional da empresa é igualmente importante para atender a compra online (Tang et al., 2016). A presença do varejo hoje apresenta uma dinâmica que vai além da dicotomia do ambiente físico ou digital. Entende-se hoje que os canais não são exclusivos: os clientes podem se relacionar com os canais físicos e digitais em momentos distintos ao longo 
da experiência de compra (Dholakia et al., 2010). A natureza sensível à localização dos smartphones abre caminho para a comunicação que é sensível à localização dos clientes (Högberg et al., 2020).

$\mathrm{Na}$ verdade, o mobile marketing é um conjunto de práticas que permite que as organizações se comuniquem e se envolvam com seu público de maneira interativa e relevante por meio de qualquer dispositivo ou rede móvel. Mais recentemente, o celular tem sido analisado sob o modelo $\mathrm{O} 2 \mathrm{O}$ (online-to-offline). Entre outras coisas, o modelo $\mathrm{O} 2 \mathrm{O}$ vê o online como um mecanismo de descoberta para os clientes, que funciona como um gerador de tráfego para os varejistas e que permite a compra offline. No entanto, como Chiang et al. (2018) apontou, ainda existe a necessidade de um modelo complementar para as empresas atraírem clientes adicionais para as lojas físicas. Pantano e Priporas (2016) destacam a importância de integrar as configurações físicas do varejo com as oportunidades online. Buscar compras nos pontos de coleta é um benefício percebido, evitando problemas na entrega e permitindo que os clientes verifiquem as mercadorias, reduzindo os riscos (Pantano \& Priporas, 2016). Além disso, as compras off-line pesam positivamente na possibilidade de inspeção do produto e nos aspectos sociais da experiência de compra. Por outro lado, as compras online oferecem o benefício da conveniência, com a remoção de barreiras temporais e espaciais.

Teorias seminais que examinam a aceitação de novas tecnologias, como a Teoria da Difusão da Inovação (Rogers, 1983), Modelo de Aceitação de Tecnologia (TAM, Davis, 1989) e Teoria Unificada de Aceitação e Uso de Tecnologia (UTAUT, Venkatesh et al., 2003) são o núcleo da maioria das pesquisas sobre compras pelo celular (Gupta \& Arora, 2017; Hubert et al., 2017; San-Martín et al., 2016). Os estudos mais citados são apresentados na Tabela 1. Alguns desses estudos sugerem fatores que aumentam a adoção de compras pelo celular (Shankar et al., 2010; Zhang \& Mao, 2008), tendo um efeito positivo ou funcionando como mecanismos de mediação chave, enquanto outros são focados em fatores que restringem essa adoção de tecnologia, como riscos percebidos e, mais importante, eles apresentam o efeito do mobile marketing no processo de tomada de decisão do cliente (Bellman et al., 2011; Fong et al., 2015). Entretanto, é importante também destacar que as características intrínsecas dos indivíduos podem afetar a intenção de adoção de dispositivos móveis (por exemplo, Patsiotis et al., 2020). Participantes jovens e experientes em mídia social com um grande interesse em compras geralmente são compradores em rede (Pantano \& Gandini, 2018). Consumidores que se sentem oprimidos pela tecnologia e que são céticos sobre seu correto funcionamento são inibidos para adotar novas tecnologias (Parasuraman \& Colby, 2015). Por outro lado, clientes 
que possuem uma visão positiva da tecnologia (Gupta \& Arora, 2017; Parasuraman \& Colby, 2015), como os pioneiros da tecnologia e líderes influentes, geralmente são motivados a adotar inovações tecnológicas. 
Tabela 1 - Marketing móvel - Artigos mais citados

\begin{tabular}{|c|c|c|c|c|c|c|c|}
\hline Autores & Principais resultados & $\begin{array}{r}2016 \\
435 \\
\end{array}$ & $\begin{array}{r}2017 \\
551 \\
\end{array}$ & $\begin{array}{r}2018 \\
591 \\
\end{array}$ & $\begin{array}{r}2019 \\
908 \\
\end{array}$ & $\begin{array}{r}2020 \\
468 \\
\end{array}$ & $\begin{array}{r}\text { Total } \\
4090 \\
\end{array}$ \\
\hline Shankar, Venkatesh, Hofacker e Naik (2010) & $\begin{array}{l}\text { Atividades do consumidor no celular, segmentos do consumidor no celular, } \\
\text { facilitadores e inibidores, propriedades-chave de dispositivos móveis, atividades de } \\
\text { marketing e competição. }\end{array}$ & 35 & 30 & 27 & 35 & 17 & 229 \\
\hline Shankar e Balasubramanian (2009) & $\begin{array}{l}\text { Impulsionadores da adoção de dispositivos móveis, influência do marketing móvel } \\
\text { na tomada de decisão de consumidores, formulação de uma estratégia móvel e } \\
\text { marketing mobile no contexto global. }\end{array}$ & 22 & 26 & 21 & 28 & 5 & 178 \\
\hline Lamberton e Stephen (2016) & $\begin{array}{l}\text { Mídia social como facilitador da impressão individual, ferramenta de suporte de } \\
\text { decisão e fonte de inteligência de mercado. }\end{array}$ & 2 & 20 & 42 & 77 & 33 & 174 \\
\hline Scharl, Dickinger, e Murphy (2005) & $\begin{array}{l}\text { Características da mensagem e do canal influenciam três medidas de sucesso: } \\
\text { atenção do consumidor, intenção e comportamento. }\end{array}$ & 15 & 13 & 12 & 14 & 7 & 164 \\
\hline $\begin{array}{l}\text { Bellman, Potter, Treleaven-Hassard, Robinson, } \\
\text { e Varan (2011) }\end{array}$ & $\begin{array}{l}\text { Aplicativos tem impacto persuasivo positivo no interesse de determinadas categorias } \\
\text { de produtos. Aplicativos informacionais são mais efetivos em mudar intenção } \\
\text { de compra. }\end{array}$ & 22 & 19 & 24 & 29 & 16 & 137 \\
\hline Kaplan (2012) & $\begin{array}{l}\text { O que é mídia social mobile, o que não é, e como se diferencia de outras aplicações } \\
\text { móveis. Como empresas podem usar mídia social móvel para pesquisa de marketing, } \\
\text { comunicação, promoções de venda / descontos e desenvolvimento de relacionamento. }\end{array}$ & 24 & 27 & 22 & 12 & 12 & 135 \\
\hline Zhang e Mao (2008) & $\begin{array}{l}\text { Dois itens de TAM, utilidade percebida e facilidade de uso de promoção por SMS, } \\
\text { foram preditoras da intenção de uso. Confiança em publicidade por SMS e normas } \\
\text { subjetivas também contribuíram para intenção de uso. }\end{array}$ & 7 & 10 & 5 & 10 & 6 & 127 \\
\hline Varnali e Toker (2010) & $\begin{array}{l}\text { Classificação da literatura de mobile marketing e para acessar o estado da arte para } \\
\text { facilitar pesquisa futura. }\end{array}$ & 10 & 12 & 11 & 11 & 5 & 109 \\
\hline Winer (2009) & $\begin{array}{l}\text { Os novos tipos de mídias que empresas estão usando para engajar consumidores } \\
\text { e os desafios que apresentam na perspectiva de gerentes de marketing. }\end{array}$ & 12 & 15 & 8 & 9 & 8 & 103 \\
\hline Fong, Fang, e Luo (2015) & $\begin{array}{l}\text { Alvos competitivos por localização produziram um retorno incremental com relação } \\
\text { a níveis de desconto promocionais, enquanto o uso de alvos por localização produziu } \\
\text { retornos decrescentes de níveis de desconto. }\end{array}$ & 10 & 22 & 21 & 31 & 8 & 93 \\
\hline
\end{tabular}

Fonte: As autoras. 
O uso de dispositivos móveis é sustentado pelo interesse por inovação do cliente e apego pessoal às tecnologias móveis (Pantano \& Priporas, 2016). A confiança no celular, consequentemente, influencia a intenção dos consumidores de se envolverem em compras pelo aparelho (Giovannini et al., 2015). Da mesma forma, a confiança no comércio online desempenha um papel importante na confiança no comércio via dispositivos móveis. Além isso, a percepção do cliente sobre a falta de contato físico - o "efeito desumanizador" (Parasuraman \& Colby, 2015, p. 62) - ainda é ambígua, funcionando como um condutor para alguns e como um inibidor para outros (Chaparro-Peláez, Agudo-Peregrina, \& Pascual-Miguel, 2016; Parasuraman \& Colby, 2015).

Gupta e Arora (2017) trouxeram novas lentes para o mobile shopping usando a teoria do raciocínio comportamental, analisando "motivos a favor" e "motivos contra". Conforme pontuaram, os clientes assumem compromissos de custo-benefício nas decisões de compra. Antes disso, Maity e Dass (2014) também aplicaram a teoria do raciocínio comportamental, associada à teoria da riqueza de conteúdo da mídia, a fim de investigar o impacto desta característica na escolha do canal dos clientes: seja ele a loja, e-commerce ou m-commerce. Os clientes preferem adotar o canal móvel para compras em tarefas de tomada de decisão mais simples, devido à baixa intensidade de conteúdo da mídia (Maity \& Dass, 2014). A compra pelo celular ocorre predominantemente em contextos de baixa consideração. Não é adequado para categorias de envolvimento mais altas, pelo menos não como um ponto de contato principal (Wang et al., 2015).

\section{Estratégias de promoções mobile: notificações push}

Os avanços nas tecnologias móveis estão afetando o comportamento de consumo, especialmente a partir de uma série de estratégias de promoção pull e push. De acordo com Molitor et al., (2015), estratégias pull diferem-se das estratégias push em três categorias distintas: i) percepção do usuário, ii) interação com cupons / anúncios e iii) design de interface.

Em geral, as notificações pull usam tecnologia móvel wi-fi e torre de celular; são entregues via aplicativo, internet móvel ou código de barras móvel; está associado à mentalidade de compra planejada e tem uma janela de resgate prolongada. As notificações push, por outro lado, usam tecnologia de triangulação de torre, wi-fi, geo-fence e beacon; são entregues via SMS, texto ou aplicativo; está associado a uma mentalidade de compra por impulso e tem uma janela de resgate imediato (Andrews et al., 2016). Estratégias pull em dispositivos móveis tendem a ser menos frequentemente consideradas spam e menos intrusivas, 
dando aos usuários mais controle sobre suas interações com o provedor, uma vez que se refere a usuários que procuram ativamente por um produto ou serviço.

Tang et al. (2016) aplicaram uma abordagem inovadora para a adoção de compras móveis ao analisar esse fenômeno sob a perspectiva da migração de canal e a teoria de interligação push-pull. Com base em estudos de migração humana, essa teoria sugere que existem fatores negativos na origem que impulsionam indivíduos, enquanto fatores positivos no destino que agem para atraí-los, e, por fim, fatores de atracação que facilitam ou inibem suas decisões de migração. O modelo de Tang et al. (2016) testou a inconveniência dos canais tradicionais de internet e a percepção de preços altos como fatores de pressão; utilidade percebida e facilidade de uso percebida de compras móveis como fatores de atração e altos custos de mudança e baixa segurança / privacidade como fatores de retenção que influenciam as decisões dos clientes sobre a migração de compras online (com base em PC) para compras móveis. O custo da mudança não foi significativo nos resultados, mas a segurança esteve em linha com o que outros estudos de aceitação da tecnologia móvel já demonstraram (Hubert et al., 2017; San-Martín et al., 2016).

Pesquisadores relataram de forma consistente a relação entre o mobile marketing e as respostas dos indivíduos em relação ao comportamento do último clique. No entanto, o interesse em investigar como a interação via celular impulsiona as visitas às lojas está se tornando recentemente o tema de investigação (Tabela 2). 
Tabela 2 - Pesquisa em Mobile marketing e comportamento de compra offline, promoções e geolocalização

\begin{tabular}{|c|c|c|}
\hline & Investigação & Autores \\
\hline 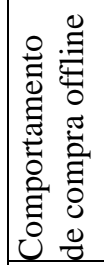 & $\begin{array}{l}\text { Como tecnologias móveis afetam o } \\
\text { comportamento de compra no varejo físico. }\end{array}$ & $\begin{array}{l}\text { Andrews et al. (2016), Groß (2015), } \\
\text { Bakopoulos et al. (2017), Shankar et al. (2016) }\end{array}$ \\
\hline 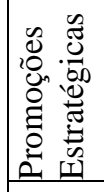 & Promoções móveis pull e push no varejo & $\begin{array}{l}\text { Beeck e Toporowski (2017), } \\
\text { Fong et al. (2015), Tang et al. (2016) }\end{array}$ \\
\hline 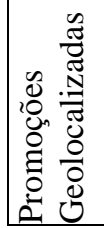 & Promoções móveis geolocalizadas & $\begin{array}{l}\text { Verhoef et al. (2017), Grewal et al. (2018), } \\
\text { Ieva et al. (2018), Pantano e Gandini (2018), } \\
\text { Fulgoni e Lipsman (2016), Grewal et al. (2016), } \\
\text { Hui et al. (2013), Tong et al. (2020), Ghose et al. } \\
\text { 2019) }\end{array}$ \\
\hline
\end{tabular}

Fonte: Elaborado pelas autoras.

A Figura 1 apresenta uma análise dos grupos de autores conectados pelo VoSviewer. Escolhemos o Social Sciences Citation Index (SSCI) da Web of Science como base de dados e definimos um critério para a busca dos artigos. Nossa pesquisa foi restrita ao tópico (título, palavras-chave ou resumo) usando as palavras-chave 'Location-Based Marketing' ou 'Mobile Marketing' e seus derivados, no período de 1979 a 2020. Mas, apenas a partir de 2004, o campo de pesquisa em Mobile marketing realmente mostra citações. Em seguida, foi realizada uma análise de cluster com o apoio do VOSviewer 1.6.13, que permite a análise quantitativa de uma área de pesquisa por meio de dados históricos (autores, citações, cocitações, entre outros), bem como identificar as principais tendências (Bonilla et al., 2015). O VOSviewer auxilia na compreensão de redes bibliométricas por meio da visualização de mapas.

Conforme mostrado na Figura 1, o cluster vermelho concentra a pesquisa sobre aceitação de dispositivos móveis (Bauer et al., 2005; Scharl et al., 2005; Tsang et al., 2004), mas com foco em campanhas móveis, principalmente na aceitação de mensagens SMS. Há uma ligação mais forte de citações do cluster vermelho para o verde com o trabalho de Barwise e Strong (2002), explorando a eficácia das mensagens de texto SMS como um meio de publicidade para alcançar jovens e adultos. Diferente de trabalhos anteriores, que concentraram esforços no mobile marketing mas com foco principalmente na aceitação do contexto de novas tecnologias (cluster azul) (cf. Davis, 1989; Rogers, 1983; Venkatesh et al., 2003), um recente fluxo de pesquisa distinto (cluster verde), concentrou-se principalmente em investigações importantes sobre como conectar os esforços online ao comportamento offline. Esses estudos 
avaliam como as promoções mobile direcionadas podem atrair clientes adicionais para lojas físicas e também aumentar os gastos não planejados (Hui et al., 2013).

As notificações push oferecem uma maneira conveniente de estimular compras não planejadas ao atingir os clientes quando eles estão perto de uma loja, ponto de compra ou consideração de compra (Andrews et al., 2016, p. 16). Essas notificações podem ser altamente eficazes, mas a localização real do indivíduo tem um efeito importante sobre como eles respondem a essa estratégia. Além disso, o uso inadequado de tecnologia pode dissuadir clientes em potencial ao invés de atraí-los. Beeck e Toporowski (2017) forneceram evidências dos riscos e benefícios potenciais do envio de mensagens móveis aos consumidores como parte da estratégia de integração do digital e a condução à loja física. De acordo com Beeck e Toporowski (2017), segmentação para celular deve ser influenciada pelo conteúdo da mensagem móvel e pela localização do cliente ao receber a mensagem. Isso nos leva a vincular promoções pull e push móveis às estratégias de geolocalização.

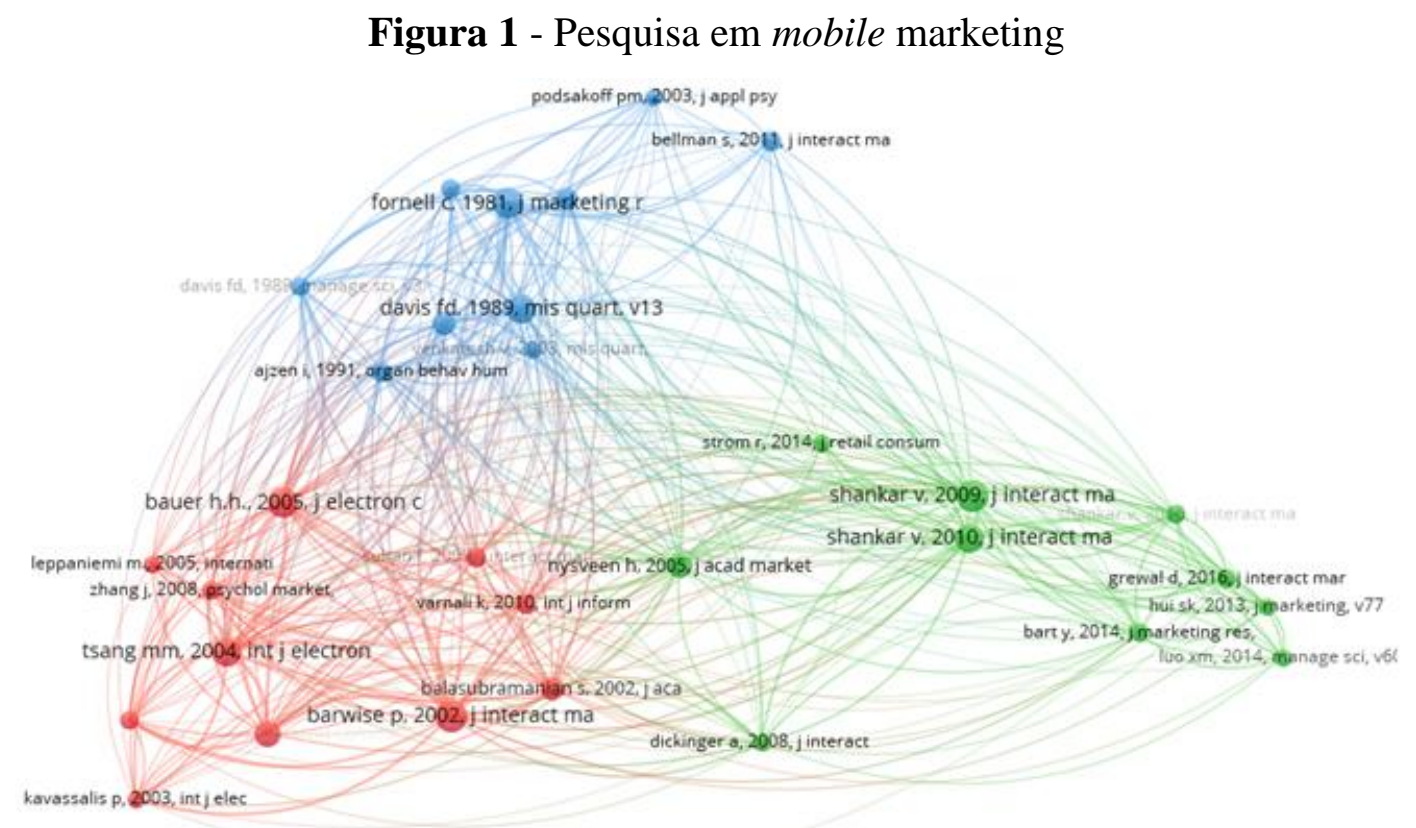

Fonte: VosViewer - Acoplamento bibliométrico.

\section{Marketing em dispositivos móveis e promoções de geolocalização}

O marketing baseado em localização, ou ações baseadas em geolocalização, ou geofencing, é um dos campos mais férteis para o mobile marketing. A segmentação por 
localização de clientes dentro de certas áreas designadas (normalmente perto da localização da própria empresa) é conhecida como geofencing (perímetro de ativação). A capacidade de oferecer suporte a aplicativos baseados em localização é um recurso exclusivo dos dispositivos móveis (Grewal et al., 2016). O marketing geocomportamental refere-se à capacidade de atingir públicos e/ou usuários únicos com base no contexto de um determinado local ou em comportamentos de locais anteriores ou presentes (MMA, 2019). As tecnologias móveis capacitam pesquisadores e gerentes a extrair insights sobre fenômenos de marketing de uma forma que era impraticável estudar no passado, uma vez que as tecnologias móveis fornecem acesso à presença dos clientes em tempo real (Cliquet, 2021; Fong et al., 2015), em conjunto com uma série de dados fornecidos por este dispositivo mais íntimo.

$\mathrm{O}$ marketing digital engloba o mobile marketing e, embora esses conceitos tenham muitas semelhanças, eles não são exatamente os mesmos (Maity \& Dass, 2014). A construção móvel pode abranger o dispositivo, a tecnologia, o canal ou outros aspectos. Em relação ao dispositivo, móvel é qualquer dispositivo portátil conectado centralmente que pode ser usado em movimento, como um smartphone ou um tablet (Shankar et al., 2016). Apesar das semelhanças, o online e o móvel trazem experiências diferentes para o cliente. Ambos têm em comum a separação do momento da compra do momento da coleta/consumo, eliminando as tradicionais barreiras temporais e espaciais do varejo físico (Pantano \& Priporas, 2016). Este é o consumo a qualquer hora, em qualquer lugar. O consumo via smartphones permite que os indivíduos façam compras quando estão em movimento, sem restrições de tempo ou espaço (Tang et al., 2016), enquanto o e-commerce requer uma área para o PC ou notebook, o que pode impor mais restrições, como horários e locais determinados.

O diferencial mobile está justamente na singularidade que as funcionalidades dos aparelhos oferecem, principalmente a geolocalização (Cliquet, 2021). Usar a localização do indivíduo para estimular estratégias direcionadas permite inserir o contexto no processo: o produto certo, para a pessoa certa, na hora certa. Esse é um dos principais benefícios que o celular oferece devido ao seu caráter onipresente. O contexto móvel permite à empresa aproximar-se do cliente em diferentes situações e pontos de contato, ligando a oferta ao contexto de consumo. Além disso, uma promoção móvel é menos invasiva porque as notificações móveis são fáceis tanto de serem verificadas rapidamente quanto ignoradas (Fong et al., 2015, p. 728).

A segmentação por local tem sido amplamente adotada por profissionais de mobile marketing, com a Ad Networks já fornecendo inventário de mídia com base em cercas 
geográficas. As ações de geolocalização visam principalmente impulsionar o comportamento de compra não programada, uma vez que geralmente ocorrem perto do ponto de venda. Há também a segmentação por localização competitiva, a prática de promoções para clientes próximos à localização de um concorrente, usando promoções de geolocalização para celular como armas competitivas (Fong et al., 2015). Como mencionado, a eficácia das promoções móveis é orientada pelo princípio do contexto - tomar a ação certa no lugar e na hora certa (Verhoef et al., 2017). Como Fong et al. (2015, p. 726) sugerem, as promoções móveis podem atingir os consumidores quando e onde eles são mais receptivos. A diferença entre um anúncio ser percebido como uma interrupção ou um simpático cumprimento geralmente está no momento. Nesses casos, tanto a localização quanto o momento da mensagem são cruciais, e o desafio é direcionar "momentos de relevância" ao longo da jornada do cliente (Bakopoulos et al., 2017).

Uma pesquisa recente mostrou o efeito positivo do marketing baseado em localização nas respostas atitudinais e comportamentais dos usuários, como a intenção de resgatar cupons (Beeck \& Toporowski, 2017), taxa de compra (Fong et al., 2015) e cliques nos cupons (Molitor et al., 2015). A Tabela 3, para o melhor do conhecimento dos autores, apresenta todos os estudos que investigaram empiricamente o marketing baseado em geolocalização até o momento. No entanto, pesquisas futuras ainda são necessárias, especialmente usando experimentos de campo com consumidores reais e potenciais, a fim de melhor explicar e fornecer avanços para a atual pesquisa de marketing baseada em geolocalização.

Embora alguns dos estudos apresentados tenham adotado uma metodologia de experimento de campo (Dubé et al.2017; Hui et al., 2013; Luo et al., 2014), eles se concentraram principalmente nas respostas dos indivíduos a notificações push que ofereciam desconto de cupons. No entanto, vale ressaltar que o tipo de produto, características do consumidor, horário e local da mensagem recebida podem também influenciar as taxas de resgate de cupons (Beeck \& Toporowski, 2017).

Há uma variedade de tecnologias que podem ser usadas para rastreamentos de localização, como Wi-Fi, RFID, GPS ou beacons. O uso dessas tecnologias ainda é um desafio para a pesquisa experimental, mas também uma tendência futura. A resistência individual e a disponibilidade de recursos são algumas das barreiras que precisam ser superadas. $\mathrm{O}$ uso de beacons, por exemplo, depende da habilitação do bluetooth no smartphone. Uma vez esgotada a bateria dos smartphones, apenas uma pequena porcentagem de usuários o mantém ligado. De acordo com o GPS, a precisão dos dados depende da recepção do sinal e essa busca também 
esgota as baterias. Além disso, é essencialmente importante não violar as políticas de privacidade do Regulamento Geral de Proteção de Dados. As pesquisas não podem lidar com categorias como hospitais ou igrejas, por exemplo. Os possíveis critérios comportamentais devem incluir visitas a uma categoria de lugares, como restaurantes (em geral), academias, comportamento de localização offline, aplicativos instalados (aqui, é importante considerar que as crianças podem instalar aplicativos nos dispositivos dos pais ou tipo de dispositivo móvel e operadora móvel). funil de compra) e impulsionar as vendas (o funil inferior). Portanto, podemos ter como objetivo medir a consideração atitudinal (o funil superior) ou comportamental real (o funil inferior) para identificar os clientes no momento certo e usar a mídia para acionar uma resposta imediata e impulsionar a aquisição. Ou seja, há uma escolha de métricas baseadas em pesquisas de atitude e/ou métricas comportamentais reais. 
Tabela 3. Estudos anteriores sobre Promoções Mobile

\begin{tabular}{|c|c|c|c|c|c|c|}
\hline Autores & & Método & Variáveis independentes & $\begin{array}{l}\text { Variáveis } \\
\text { dependentes }\end{array}$ & Contexto & Principais conclusões \\
\hline Hui et al, 2013 & $\begin{array}{l}\text { Cupom de } \\
\text { papel }\end{array}$ & $\begin{array}{l}\text { Experimento de } \\
\text { campo }\end{array}$ & $\begin{array}{l}\text { Duração do caminho na loja, } \\
\text { impulsividade, orçamento de } \\
\text { compra e dados demográficos. }\end{array}$ & Gasto não planejado & $\begin{array}{l}\text { Cupom de promoção por celular. Os participantes } \\
\text { concordaram em usar um cinto PathTracker, } \\
\text { incorporado com uma etiqueta RFID. }\end{array}$ & $\begin{array}{l}\text { Efeitos offline (ex, distância percorrida nas lojas e gastos) de cupons } \\
\text { entregues online por celular. }\end{array}$ \\
\hline Luo et al, 2014 & Push (SMS) & $\begin{array}{l}\text { Experimento de } \\
\text { campo }\end{array}$ & $\begin{array}{l}\text { Distância geográfica e } \\
\text { temporal }\end{array}$ & $\begin{array}{l}\text { Resposta a desconto } \\
\text { em ingressos de } \\
\text { cinema }\end{array}$ & $\begin{array}{l}\text { Promovido em cooperação com Cinemas IMAX. O } \\
\text { provedor de internet enviou mensagens SMS } \\
\text { promovendo ingressos com desconto. Os destinatários } \\
\text { compraram ingressos de cinema baixando o aplicativo } \\
\text { de ingresso de cinema. }\end{array}$ & $\begin{array}{l}\text { Para distâncias próximas aos cinemas, a probabilidade de resgate é } \\
\text { maior se os cupons forem enviados no mesmo dia. Para distâncias não } \\
\text { próximas, um lead time promocional de um dia tem maior } \\
\text { probabilidade de resgate. }\end{array}$ \\
\hline Danaher et al, 2015 & Push (SMS) & $\begin{array}{l}\text { Painel /Dados de } \\
\text { observação }\end{array}$ & $\begin{array}{l}\text { Localização e características } \\
\text { do cupom }\end{array}$ & $\begin{array}{l}\text { Resposta do } \\
\text { consumidor ao cupom }\end{array}$ & $\begin{array}{l}\text { Cupons de celular enviados a visitantes de um } \\
\text { shopping por terceiros. }\end{array}$ & $\begin{array}{l}\text { Local e horário de entrega tem influência significativa na taxa de } \\
\text { resgate. }\end{array}$ \\
\hline $\begin{array}{l}\text { Fong, Fang and Luo, } \\
2015\end{array}$ & Push (SMS) & $\begin{array}{l}\text { Experimento de } \\
\text { campo randomizado }\end{array}$ & $\begin{array}{l}\text { Segmentação por localização } \\
\text { competitiva e níveis de } \\
\text { desconto }(20,40,60 \%) \text { - geo- } \\
\text { conquesting }\end{array}$ & Taxa de compra & $\begin{array}{l}\text { Ofertas promocionais foram enviadas a usuáiros } \\
\text { mobile localizados perto do local do varejista, de um } \\
\text { competidor e de um local referência. }\end{array}$ & $\begin{array}{l}\text { Descontos altos são ideais para a localização de um concorrente, } \\
\text { enquanto os descontos médios são ideais para a localização focal. Taxa } \\
\text { geral de resgate de 2,5\% em todas as combinações de tratamento. }\end{array}$ \\
\hline Molitor et al, 2016 & Pull & $\begin{array}{l}\text { Experimento de } \\
\text { campo randomizado } \\
\text { de larga escala }\end{array}$ & $\begin{array}{l}\text { Distância e classificação de } \\
\text { exibição }\end{array}$ & $\begin{array}{l}\text { Clique no cupom } \\
\text { (clique como resposta } \\
\text { positiva) }\end{array}$ & $\begin{array}{l}\text { Agregador de cupons mobile, envolvendo 3,152 lojas } \\
\text { em 2,589 cidades da Alemanha, com } 13 \text { categorias de } \\
\text { produtos. }\end{array}$ & $\begin{array}{l}\text { O design de interface de cupom mais eficaz é baseado em ofertas } \\
\text { classificadas por distância; distâncias maiores diminuem a } \\
\text { probabilidade de escolher cupons. A compensação entre desconto e } \\
\text { distância geográfica é de } 148 \text { metros por ponto percentual de } \\
\text { desconto. }\end{array}$ \\
\hline $\begin{array}{l}\text { Dubé, Fang, Fong, \& } \\
\text { Luo, } 2017\end{array}$ & Push (SMS) & $\begin{array}{l}\text { Experimento de } \\
\text { campo }\end{array}$ & $\begin{array}{l}\text { Preços aleatórios de cinemas } \\
\text { concorrentes e localização do } \\
\text { consumidor }\end{array}$ & Compra de ticket & $\begin{array}{l}\text { Uma promoção de SMS consistia em uma oferta para } \\
\text { comprar um voucher para qualquer filme 2D exibido } \\
\text { em um determinado cinema no dia em que a } \\
\text { mensagem SMS foi enviada. }\end{array}$ & $\begin{array}{l}\text { Estudo de geoconquista. As descobertas demonstram a importância de } \\
\text { considerar a resposta do concorrente ao testar uma nova meta de } \\
\text { preços. }\end{array}$ \\
\hline $\begin{array}{l}\text { Beeck and } \\
\text { Toporowski, } 2017\end{array}$ & Pull & Experimento online & $\begin{array}{l}\text { Localização (casa, cidade, loja) } \\
\text { e conteúdo (cupom, mensagem } \\
\text { promocional) }\end{array}$ & Intenção de resgate & Aplicativo de desconto de shopping. & Uso baixo de descontos em aplicações mobile. \\
\hline $\begin{array}{l}\text { Ghose, Li, \& Liu, } \\
2019\end{array}$ & SMS coupons & $\begin{array}{l}\text { Experimento de } \\
\text { campo randomizado } \\
\text { de larga escala }\end{array}$ & $\begin{array}{l}\text { Sem anúncio; anúncio de uma } \\
\text { loja aleatória; anúncio baseado } \\
\text { em informação de localização; } \\
\text { anúncio baseado em } \\
\text { informação de trajetória. }\end{array}$ & Resgate do cupom & $\begin{array}{l}\text { Junho de } 2014 \text { em um shopping com mais de } 300 \\
\text { lojas. }\end{array}$ & $\begin{array}{l}\text { A segmentação para celular com base na trajetória pode levar a uma } \\
\text { probabilidade de resgate mais alta, comportamento de resgate mais } \\
\text { rápido e valores de transação mais altos. }\end{array}$ \\
\hline $\begin{array}{l}\text { Högberg, Wästlund, } \\
\text { Aas, Hjemdahl, \& } \\
\text { Nordgård, } 2020\end{array}$ & $\begin{array}{l}\text { Push } \\
\text { notification }\end{array}$ & $\begin{array}{l}\text { Experimento de } \\
\text { campo }\end{array}$ & $\begin{array}{l}\text { Rotular participantes de acordo } \\
\text { com uma característica vs } \\
\text { anúncio neutro }\end{array}$ & $\begin{array}{l}\text { Dados geográficos } \\
\text { usando iBeacon (visita } \\
\text { ao local) }\end{array}$ & $\begin{array}{l}\text { Mensagens de celular enviadas a visitantes que } \\
\text { moravam em um raio próximo ao Dyreparken Park, } \\
\text { na Noruega. }\end{array}$ & $\begin{array}{l}\text { O rótulo teve um efeito positivo e significativo em levar os visitantes } \\
\text { até o local alvo. }\end{array}$ \\
\hline
\end{tabular}

Fonte: As autoras 
Alcançar os clientes no lugar certo e na hora certa deve resultar em taxas de resposta mais altas. Além disso, as promoções oportunas para clientes em locais de destino devem produzir um efeito incremental positivo sobre as promoções não direcionadas ou assíncronas (Fong et al., 2015; Molitor et al., 2015). Em resumo, os dados de pesquisas anteriores apoiam a previsão de que a proximidade de locais físicos e o conteúdo da mensagem móvel são aspectos importantes das estratégias de mobile marketing nos esforços de O2O. Sob tal perspectiva, a interação com uma mensagem via dispositivo móvel precisa ser relevante para o contexto do consumidor. Com base na pesquisa sobre mobile marketing e comportamento de compra offline, estratégias de promoção e de promoções por geolocalização, resumimos a seguir as principais descobertas relacionadas a essa temática e apresentamos uma agenda de pesquisa com foco na localização e notificações push baseadas em a) visitas à loja, b) oferta de cupons, c) conteúdo personalizado e d) conteúdo de alto engajamento (Figura 2).

Figura 2 - Agenda de pesquisa de marketing baseado em geolocalização

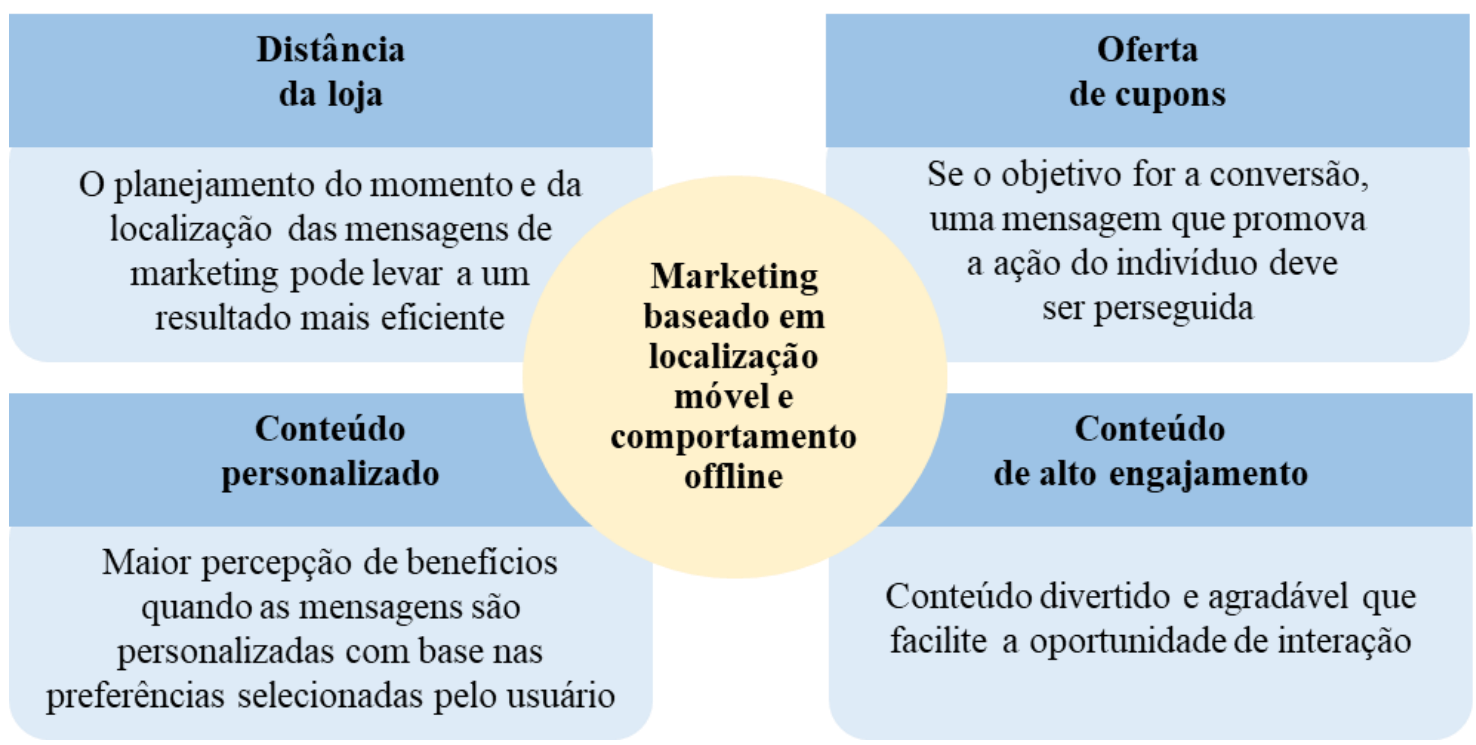

Fonte: Elaborado pelas autoras.

Diferentemente dos trabalhos anteriores, que consideraram principalmente as respostas online para online, mas à luz dos argumentos de tais trabalhos, resumimos as descobertas que podem estimular um trabalho adicional neste campo nascente. Nosso esforço é discutir como entregar um conteúdo de mensagem móvel mais eficaz, com base em dados de geolocalização, a fim de impulsionar as visitas à loja e conectar os esforços online ao comportamento offline. 


\subsection{Notificações push com base na localização e visitas à loja}

Localização e outros sinais de dados permitem que as empresas segmentem consumidores que possuem uma tendência maior de responder positivamente à oferta promocional (Bakopoulos et al., 2017). A segmentação comportamental e a segmentação contextual justificam seu custo incremental e melhoram o desempenho dos resultados da campanha: mais consideração, mais vendas (Bakopoulos et al., 2017). A segmentação contextual refere-se à identificação de consumidores que estavam navegando em conteúdo relevante sobre a categoria em seus dispositivos móveis. No entanto, as ações de geolocalização têm como objetivo principal potenciar comportamentos de compra não programados (Hui et al., 2013), uma vez que normalmente ocorrem perto do ponto de venda.

Quando você sabe onde os consumidores estão e como eles se comportam, não só pode personalizar as ofertas, mas também dar a eles recompensas e uma experiência personalizada. Os resultados dos estudos de Grewal et al. (2018, p. 102) indicam que o uso do telefone celular na loja pode aumentar as compras em geral porque os indivíduos "desviam de seu ciclo de compras convencional". Em um estudo anterior realizado no Walmart, a ativação por local teve um impacto maior na visitação à loja do que a ativação de compradores anteriores (Bakopoulos et al., 2017).

Dessa forma, ações baseadas em localização revelam uma oportunidade de aprimorar a experiência do cliente na loja física e a integração $\mathrm{O} 2 \mathrm{O}$ da marca. "A segmentação por proximidade, quando combinada com unidades de exibição móvel expansível, também melhora o impacto da publicidade em termos de direcionar o tráfego de pedestres" (Bakopoulos et al., 2017, p. 450). O planejamento do momento e da localização das mensagens de marketing pode levar a um resultado mais eficiente. Molitor et al. (2015) analisaram se as promoções móveis que são acionadas por cercas geográficas (ou seja, enviadas quando um cliente entra em uma área predefinida em torno da loja de promoção) são mais eficazes em comparação com as recebidas sem estas cercas. Isso leva à primeira proposição.

Proposição 1: As notificações push baseadas na localização, quando enviadas perto da loja de destino, aumentam o número de visitas ao ponto de vendas físico. 


\subsection{Notificações push com base em localização e oferta de cupons}

Em termos funcionais, os cupons baseados em localização podem ser enviados aos usuários (ou seja, push móvel) ou fornecidos sob demanda por meio de aplicativos específicos, nos quais os usuários podem navegar intencionalmente pelos cupons disponíveis (pull móvel) (Xu et al., 2009). Basicamente, as ofertas de push e pull móveis variam no mecanismo de entrega. Em um cenário de pull, os usuários procuram e solicitam explicitamente essas ofertas (Molitor et al., 2015). Já em um cenário push, os usuários não explicitamente pedem por essas ofertas; as ofertas são enviadas automaticamente para eles, com base em uma variedade de critérios de segmentação.

Estudos anteriores demonstraram que a distância até o ponto de venda impacta a probabilidade de compra (Molitor et al., 2015), principalmente se houver algum tipo de cupom. Pesquisas mostram maior resgate de cupons enviados para dispositivos móveis (Hui et al., 2013; Klabjan \& Pei, 2011). A razão pela qual a distância pode ser mais importante em dispositivos móveis (em comparação com PCs) é que os aplicativos de cupons móveis são usados como um meio de informação onipresente e com a intenção de trazer os clientes (de volta) às lojas físicas de varejo (Molitor et al., 2015).

Se o objetivo da campanha é o branding, o fato de o usuário estar exposto à marca via comunicação institucional é relevante. Alcançar a visibilidade e, talvez, o envolvimento deve ser suficiente. "O celular é particularmente eficaz para marcas estabelecidas, que os clientes têm menos necessidade de pesquisar ou validar" (Bakopoulos et al., 2017, p. 449). No entanto, se o objetivo for a conversão, uma mensagem que promova a ação do cliente deve ser perseguida. Tal como Shankar et al. (2016) destacam, promoções inesperadas aumentam a sensação de acaso no processo móvel, o que ajuda a aumentar o engajamento do cliente.

No entanto, o valor percebido de um cupom baseado em localização pode depender da localização geográfica real onde os usuários abrem e acessam seu aplicativo de cupom móvel (Molitor et al., 2015). De acordo com Fong et al. (2015), é limitado concluir que a capacidade de resposta local para promoções móveis é meramente uma função da proximidade com as próprias lojas de um varejista. Por exemplo, Fong et al. (2015) analisaram os efeitos dos percentuais de desconto em locais competitivos, com a cooperação de um provedor de serviços móveis. Eles chegaram à conclusão de que descontos elevados eram ótimos para a localização competitiva, enquanto descontos médios eram ótimos para a localização focal. Os resultados da pesquisa de Beeck e Toporowski (2017) indicam que as mensagens móveis podem ser altamente eficazes para usuários de aplicativos de desconto quando o cliente está perto da loja. 
Proposição 2: As visitas ao ponto de venda físico geradas por notificações mobile baseadas em geolocalização são maiores quando o conteúdo é promocional do que quando o conteúdo é institucional.

\subsection{Notificações push com base em localização e conteúdo personalizado}

Uma palavra-chave na promoção móvel é permissão. "As informações de localização em tempo real são potencialmente bastante confidenciais e os clientes nem sempre entendem os longos termos e condições com os quais concordaram" (Verhoef et al., 2017, p. 7). Tecnologias como beacons, com a permissão dos clientes, permitem que os varejistas consigam ir além da segmentação. Os varejistas têm a oportunidade de coletar dados, medir o comportamento de compra em tempo real e personalizar promoções (Beeck \& Toporowski, 2017). Os beacons móveis são uma ferramenta de comunicação de marketing totalmente diferente das mensagens móveis, pois exigem que o cliente instale o aplicativo. Mas, uma vez instalada, o uso da tecnologia móvel pelos clientes gera informações que podem ser capturadas pelas empresas para fins de direcionamento (Verhoef et al., 2017). O processo de ativação mobile é extremamente delicado e por isso deve ser muito bem planejado.

Por causa do efeito da geolocalização ao estimular o comportamento de compra não programado, essas compras por impulso podem gerar arrependimento e um sentimento negativo nos clientes. Para minimizar esses efeitos negativos, as notificações push devem de fato conter um benefício que agregue valor ao cliente, de preferência customizado (Tong et al., 2020). Há uma percepção comum de que anúncios mais bem direcionados necessariamente requerem acesso aos dados pessoais dos clientes, com técnicas de direcionamento aprimoradas sendo vantajosas para as empresas (Kim et al., 2019). Anúncios bem direcionados são objetivamente mais personalizados; portanto, eles devem, por definição, ser mais relevantes e interessantes para os clientes (Kim et al., 2019, p. 908). Direcionar um anúncio com base no comportamento do cliente pode aumentar o ajuste pessoa-produto e, consequentemente, a eficácia do anúncio.

As teorias de auto-divulgação sugerem que a disposição dos clientes em divulgar informações pessoais é baseada em suas avaliações dos custos e benefícios percebidos (Andrade, Kaltcheva, \& Weitz, 2002, p. 350). Podemos traçar um paralelo com notificações push que possuem permissão de envio: para que os clientes divulguem sua localização às empresas, eles avaliam os custos e benefícios oferecidos. Outro benefício do mobile são seus serviços diferenciados, principalmente relacionados à possibilidade de ofertas baseadas na localização em tempo real (Faqih \& Jaradat, 2015; Gupta \& Arora, 2017). Essa oferta vem na 
forma de mensagens personalizadas com base nas preferências selecionadas pelo usuário, exigindo menos esforço para encontrar informações (Eastin et al., 2016). Em geral, os sistemas podem adaptar seu comportamento ao uso individual, reconhecendo automaticamente algumas informações sobre os clientes (Pantano \& Priporas, 2016).

Proposição 3: As visitas ao ponto de venda físico geradas por notificações móveis baseadas em geolocalização são maiores quando o conteúdo é personalizado.

\subsection{Notificações push com base em localização e conteúdo de alto engajamento}

Apesar do aumento do varejo móvel, os clientes ainda sentem ansiedade e falta de confiança no uso do m-commerce (Gupta \& Arora, 2017). Assim, as tarefas de compra móvel devem ser fáceis (processo de transação simples e amigável) e econômicas para atrair clientes (Tang et al., 2016). Além disso, tais tarefas devem ser também divertidas e agradáveis. De fato, o entretenimento percebido é realmente importante no m-commerce e pode fornecer uma explicação melhor para a adoção da tecnologia do que as motivações utilitárias, como a utilidade percebida (van der Heijden, 2004). No entanto, dada a limitação provocada por telas são menores, a riqueza de mídia é afetada na comunicação móvel (Pantano \& Priporas, 2016). A riqueza da mídia está relacionada à capacidade de comunicar informações ao cliente por meio de mensagens de texto, áudio, vídeo e face a face (Maity \& Dass, 2014). Além disso, a falta de interfaces amigáveis em telas menores pode se transformar em desconforto e inconveniência. Essa limitação de espaço (pequenos teclados e telas pequenas) pode tornar a interação via celular mental e fisicamente exaustiva e, portanto, cognitivamente onerosa (Sohn, Seegebarth, \& Moritz, 2017).

A riqueza da mídia é definida como o grau em que um meio pode facilitar o significado compartilhado (Daft, Lengel, \& Trevino, 1987). Estudos anteriores ampliaram a teoria da riqueza da mídia para explicar a capacidade da mídia em expressar informações ricas usando quatro aspectos: feedback imediato; múltiplas dicas; foco pessoal; e variedade de linguagem (Tseng et al., 2017). O feedback imediato refere-se à capacidade que permite uma comunicação bidirecional rápida e mensagens de resposta rápida. As dicas múltiplas referem-se a texto e ícones, quando o foco pessoal faz referência a emoções. Por fim, a variedade da linguagem envolve um grande conjunto de símbolos (Tseng et al., 2019). O uso de elementos de design de jogos é uma das estratégias úteis para aprimorar bens e serviços não relacionados diretamente a gaming, aumentando o valor para o cliente e encorajando comportamentos de criação de valor, como o engajamento (Hofacker et al., 2016). De fato, o entretenimento no cellular é um 
importante fator para satisfação e boca a boca positivo (San-Martín et al., 2016). Para ser divertido e agradável, o design do $m$-site "deve facilitar a oportunidade de interatividade entre o cliente e a empresa, ou entre vários clientes" e dar a opção de visualizar e interagir melhor com as imagens (San-Martín et al, 2016, p. 609).

Como apontado, personalizar ou direcionar anúncios torna-se mais crítico em um smartphone devido as limitações de espaço (Molitor et al., 2015). Hofacker et al. (2016) sugeriram que o uso de elementos de design de jogos executados na plataforma móvel tem o potencial de afetar o entretenimento dos clientes e também de contribuir para o engajamento na loja. Da mesma forma, Scholz e Smith (2016) observaram como a realidade aumentada pode ajudar os profissionais de marketing a otimizar suas campanhas e aumentar vários tipos de engajamento do consumidor, como engajamento usuário-marca, engajamento usuário-usuário e engajamento usuário-espectador. Oferecemos o seguinte:

Proposição 4: As visitas ao ponto de vendas offline geradas por notificações móveis baseadas em localização são maiores para conteúdo de alto engajamento.

\section{Agenda de pesquisa}

O celular apresenta-se como uma mudança de paradigma digital no varejo e uma ferramenta fundamental para aprimorar a experiência do consumidor em lojas físicas. Os clientes navegam entre os canais online e offline, mas a maioria termina em um ambiente físico. Mais da metade da navegação na web ocorre por meio de dispositivos móveis e $65 \%$ das pesquisas do Google são feitas por meio desses dispositivos (Statista, 2019). No entanto, a maioria das vendas no varejo ainda é representada por lojas físicas $(85 \%$, de acordo com o relatório de 2019 do Statista). O consumidor vive uma jornada em que passa por múltiplos canais e pontos de contato, sendo o celular o centro desse processo. Assim, a abordagem deverá ser cada vez mais multimedia e multiplataforma, aproveitando as sinergias que o marketing $\mathrm{m}^{\prime} \mathrm{v}$ oferece com os restantes canais. Em um cenário em que a maioria dos nossos minutos digitais acontecem em plataformas móveis, é uma questão de sobrevivência ter um planejamento focado no celular que abranja o potencial de novas tecnologias, como a geolocalização.

No entanto, o verdadeiro negócio por trás das promoções mobile vai além da geolocalização - ele refere-se ao contexto. Tanto o conteúdo da mensagem quanto a geolocalização são pilares importantes do contexto. Trata-se de entender quando, onde e como falar com os consumidores, de uma forma que realmente importe para eles - a chamada relevância. O telefone celular é o dispositivo que fornece a onipresença que esse processo exige. 
É o acontecimento da era do marketing da "marca na mão" (Sultan \& Rohm, 2005). A eficácia do mobile marketing é guiada pelo princípio do contexto: tomar a ação certa, no lugar certo, na hora certa.

O celular é uma via crítica para o crescimento omnicanal, não apenas em relação à conversão, mas também por facilitar o cumprimento e impulsionar a pesquisa e consideração, sendo esse o contexto ideal para notificações push. Existem várias implicações práticas no gerenciamento dos comportamentos offline dos clientes (visitas a sites offline) envolvendo-se com meios digitais de comunicação. Infelizmente, ainda existem poucos estudos sobre os efeitos dos esforços móveis no comportamento offline, sob a perspectiva do $\mathrm{O} 2 \mathrm{O}$ (Chiang et al., 2018). Tendo em vista esta etapa ainda embrionária, nossa revisão da literatura cobriu três correntes de pesquisa: a) como as tecnologias móveis afetam o comportamento offline do consumidor em lojas físicas (relacionamento online para offline), b) principais promoções móveis pull e push em ambientes de varejo e c) promoções baseadas em geolocalização. $\mathrm{O}$ referencial teórico adotado deriva de uma reflexão crítica sobre a revisão da literatura, abrangendo percepções sobre os fatores que embasariam nossas proposições apresentadas.

Baseamo-nos na literatura de marketing contextual e publicidade comportamental para postular que a promoção de geolocalização por celular direcionada ao usuário assim que ele se aproxima da loja aumenta as chances de uma resposta positiva à comunicação. Também postulamos que o efeito seria moderado pelo tipo de mensagem: promocional ou institucional. A principal suposição por trás de nossa análise é que o conteúdo e o momento da mensagem (considerando a geolocalização do indivíduo) aumentam as visitas a sites offline. Contexto e conveniência são os principais motivadores do efeito, considerando que o contexto e a conveniência são representados pela geolocalização e pelo conteúdo da mensagem. Isso fornece a base para um modelo móvel para as empresas atraírem clientes para locais físicos

Do ponto de vista gerencial, esta revisão contribui iluminando o caminho para a ativação mobile na estratégia cross-channel de varejo. Além disso, deve ajudar a compreender como o uso da tecnologia móvel pelo consumidor pode ser usado para orientá-los para compras na loja e, portanto, melhorar a alocação do orçamento de mídia de varejo e aumentar o ROI de marketing usando dispositivos móveis. Sabendo mais sobre as motivações para a adoção do celular em toda a jornada de compras em ambientes multicanal, as empresas podem implantar estratégias de marketing mais eficientes.

No entanto, embora essas notificações direcionadas tenham o poder de aumentar as experiências de compras físicas, a personalização pode, se não bem utilizada, promover efeitos 
contrários e severos e esta é uma questão importante que merece atenção futura em pesquisas. De particular relevância, notificações altamente personalizadas podem despertar preocupações com a privacidade do consumidor (Aguirre et al., 2016; Kim et al., 2019). Os varejistas devem estar cientes das preocupações com a privacidade que impedem alguns clientes de usar estímulos móveis (Beeck \& Toporowski, 2017). A prevenção de riscos (Pantano \& Priporas, 2016) e a falta de confiança desempenham um papel importante na limitação da aceitação do consumidor da tecnologia de compra móvel e pode estender-se à sua vontade de aceitar notificações push direcionadas. Este é um desafio gerencial em relação aos dados no nível pessoal para que seja possível dar vida às campanhas de marketing um-para-um.

Esta revisão pretende contribuir para as teorias de mobile marketing, geolocalização e segmentação comportamental, bem como para as teorias do comportamento do cliente omnicanal. Como Ghose, Li, e Liu (2015) reforçam, o traço digital do comportamento offline dos consumidores tornou-se cada vez mais crítico para as empresas hoje. Tal comportamento é fundamental para que seja possível compreender as preferências inerentes dos consumidores a fim de melhorar as experiências digitais do usuário e estratégias de marketing de negócios.

O mobile marketing tem o poder de ajudar as marcas a construir relacionamentos pessoais com os clientes. No entanto, existe uma linha tênue entre fazer o cliente se sentir especial e fazê-lo se sentir perseguido, revelando a importância de usar o conteúdo certo no momento certo. Os varejistas devem adotar uma mentalidade móvel se desejam executar uma estratégia omnicanal bem-sucedida. Esperançosamente, os novos caminhos de pesquisa que estão amplamente abertos em dispositivos móveis irão beneficiar os milhões de clientes que ainda não experimentaram os benefícios oferecidos por tais dispositivos.

Nossa revisão da literatura nos permitiu investigar o que se sabe até agora sobre notificações push com base em geolocalização e como as estratégias planejadas relacionadas a visitas à loja, oferta de cupons, conteúdo personalizado e conteúdo de alto envolvimento afetariam o comportamento offline do cliente em lojas físicas (relacionamento online para offline). Porém, para entender melhor a eficácia de cada uma dessas estratégias, testes empíricos são necessários. Ao testá-los, a demonstração dos efeitos esperados pode auxiliar no direcionamento da estratégia de mobile marketing, impulsionando ações de menor alcance, porém maior precisão e, portanto, com maiores taxas de conversão. Conforme mencionado anteriormente, a precisão das ações móveis ganha importância em um contexto em que os consumidores estão sobrecarregados de publicidade. Com a enorme oferta no mercado de aplicativos com as mais variadas funções e serviços, o consumidor carece de espaço na memória 
do smartphone (espaço de armazenamento) para aproveitar todos os serviços disponíveis nas lojas de aplicativos. É uma tarefa difícil envolver os consumidores em um aplicativo. Eles fazem dezenas de downloads, mas logo não encontram relevância e são desinstalados. Adicione o fato de que o celular é o dispositivo mais íntimo do consumidor, exigindo que a comunicação seja relevante e conveniente para não ser invasiva.

Confiantes, esperamos que mais pesquisas tragam insights para a próxima fase desse empolgante fenômeno móvel. Ainda assim, o desafio permanece em como transformar dados contextuais em estratégias de marketing personalizadas. A era do marketing da "marca na mão" chegou, mas ainda estamos nos familiarizando com os desafios que ela trouxe. Pense mobile.

\section{Referências}

Aguirre, E., Roggeveen, A. L., Grewal, D., \& Wetzels, M. (2016). The personalizationprivacy paradox: implications for new media. Journal of Consumer Marketing, 33(2), 98110. https://doi.org/10.1108/JCM-06-2015-1458

Andrade, E. B., Kaltcheva, V., \& Weitz, B. (2002). Self-Disclosure on the Web: The Impact of Privacy Policy, Reward, and Company Reputation. Advances in Consumer Research, 29(1), 350-354.

Andrews, M., Goehring, J., Hui, S., Pancras, J., \& Thornswood, L. (2016). Mobile Promotions: A Framework and Research Priorities. Journal of Interactive Marketing, 34, 15-24. https://doi.org/10.1016/j.intmar.2016.03.004

Bakopoulos, V., Baronello, J., \& Briggs, R. (2017). How Brands Can Make Smarter Decisions in Mobile Marketing. Journal of Advertising Research, 57(4), 447-461. https://doi.org/10.2501/JAR-2017-052

Barwise, P., \& Strong, C. (2002). Permission-Based Mobile Background: the Growth of Mobile. Journal of Interactive Marketing, 16(1), 14-24.

Bauer, H. H., Reichardt, T., Barnes, S. J., \& Marcus, M. N. (2005). Driving Consumer Acceptance of Location-Based Services in Mobile Applications: A Theoretical Framework and an Empirical Study. Journal of Electronic Commerce Research, 6(3), 181-192.

Beeck, I., \& Toporowski, W. (2017). When location and content matter: effects of mobile messages on intention to redeem. International Journal of Retail \& Distribution Management, 45(7/8), 826-843. https://doi.org/10.1108/IJRDM-09-2016-0171

Bellman, S., Potter, R. F., Treleaven-Hassard, S., Robinson, J. A., \& Varan, D. (2011). The Effectiveness of Branded Mobile Phone Apps. Journal of Interactive Marketing, 25(4), 191-200. https://doi.org/10.1016/j.intmar.2011.06.001 
Bonilla, C. A., Merigó, J. M., \& Torres-Abad, C. (2015). Economics in Latin America: a bibliometric analysis. Scientometrics, 105(2), 1239-1252. https://doi.org/10.1007/s11192015-1747-7

Chaparro-Peláez, J., Agudo-Peregrina, Á. F., \& Pascual-Miguel, F. J. (2016). Conjoint analysis of drivers and inhibitors of e-commerce adoption. Journal of Business Research, 69(4), 1277-1282. https://doi.org/10.1016/j.jbusres.2015.10.092

Chiang, I.-P., Lin, C.-Y., \& Huang, C.-H. (2018). Measuring The Effects of Online-to-Offline Marketing. Contemporary Management Research, 14(3), 167-190. https://doi.org/10.7903/cmr.18462

Cliquet, G. (2021). From Geomarketing to Spatial Marketing. In S. Colombo (Ed.), Spatial Economics Volume II: Vol. II (pp. 277-305). https://doi.org/10.1007/978-3-030-400941_10

Comscore. (2018). Global Digital Future in Focus - 2018 International Edition. Retrieved from https://www.comscore.com/Insights/Presentations-and-Whitepapers/2018/GlobalDigital-Future-in-Focus-2018

Daft, R. L., Lengel, R. H., \& Trevino, L. K. (1987). Message Equivocality, Media Selection, and Manager Performance: Implications for Information Systems. MIS Quarterly, 11(3), 355. https://doi.org/10.2307/248682

Danaher, P. J., Smith, M. S., Ranasinghe, K., \& Danaher, T. S. (2015). Where, When, and how Long: Factors that Influence the Redemption of Mobile Phone Coupons. Journal of Marketing Research, 52(5), 710-725. https://doi.org/10.1509/jmr.13.0341

Davis, F. D. (1989). Perceived Usefulness, Perceived Ease of Use, and User Acceptance of Information Technology. MIS Quarterly, 13(3), 319. https://doi.org/10.2307/249008

Dholakia, U. M., Kahn, B. E., Reeves, R., Rindfleisch, A., Stewart, D., \& Taylor, E. (2010). Consumer Behavior in a Multichannel, Multimedia Retailing Environment. Journal of Interactive Marketing, 24(2), 86-95. https://doi.org/10.1016/j.intmar.2010.02.005

Dubé, J., Fang, Z., Fong, N., \& Luo, X. (2017). Competitive Price Targeting with Smartphone Coupons. Marketing Science, 36(6), 944-975. https://doi.org/10.1287/mksc.2017.1042

Eastin, M. S., Brinson, N. H., Doorey, A., \& Wilcox, G. (2016). Living in a big data world: Predicting mobile commerce activity through privacy concerns. Computers in Human Behavior, 58, 214-220. https://doi.org/10.1016/j.chb.2015.12.050

eMarketer. (2018). Mobile Trends 201910 Predictions for What Marketers Can Expect. Retrieved from https://www.emarketer.com/content/mobile-trends-2019

Faqih, K. M. S., \& Jaradat, M. I. R. M. (2015). Assessing the moderating effect of gender differences and individualism-collectivism at individual-level on the adoption of mobile commerce technology: TAM3 perspective. Journal of Retailing and Consumer Services, 22, 37-52. https://doi.org/10.1016/j.jretconser.2014.09.006 
Fong, N. M., Fang, Z., \& Luo, X. (2015). Geo-Conquesting: Competitive Locational Targeting of Mobile Promotions. Journal of Marketing Research, 52(5), 726-735. https://doi.org/10.1509/jmr.14.0229

Fulgoni, G. M., \& Lipsman, A. (2016). The future of retail is mobile: How mobile marketing dynamics are shaping the future of retail. Journal of Advertising Research, 56(4), 346-351. https://doi.org/10.2501/JAR-2016-041

Ghose, A., Li, B., \& Liu, S. (2015). Digitizing Offline Shopping Behavior Towards Mobile Marketing. International Conference on Information Systems, 1-15.

Ghose, A., Li, B., \& Liu, S. (2019). Mobile Targeting Using Customer Trajectory Patterns. Management Science, 65(11), 5027-5049. https://doi.org/10.1287/mnsc.2018.3188

Giovannini, C. J., Ferreira, J. B., Silva, J. F. da, \& Ferreira, D. B. (2015). The effects of trust transference, mobile attributes and enjoyment on mobile trust. BAR - Brazilian Administration Review, 12(1), 88-108. https://doi.org/10.1590/1807-7692bar2015140052

Grewal, D., Ahlbom, C.-P., Beitelspacher, L., Noble, S. M., \& Nordfält, J. (2018). In-Store Mobile Phone Use and Customer Shopping Behavior: Evidence from the Field. Journal of Marketing, 82(4), 102-126. https://doi.org/10.1509/jm.17.0277

Grewal, D., Bart, Y., Spann, M., \& Zubcsek, P. P. (2016). Mobile Advertising: A Framework and Research Agenda. Journal of Interactive Marketing, 34, 3-14. https://doi.org/10.1016/j.intmar.2016.03.003

Groß, M. (2015). Mobile shopping: a classification framework and literature review. International Journal of Retail \& Distribution Management, 43(3), 221-241. https://doi.org/10.1108/IJRDM-06-2013-0119

Gupta, A., \& Arora, N. (2017). Understanding determinants and barriers of mobile shopping adoption using behavioral reasoning theory. Journal of Retailing and Consumer Services, 36(December 2016), 1-7. https://doi.org/10.1016/j.jretconser.2016.12.012

Gutierrez, A., O’Leary, S., Rana, N. P., Dwivedi, Y. K., \& Calle, T. (2019). Using privacy calculus theory to explore entrepreneurial directions in mobile location-based advertising: Identifying intrusiveness as the critical risk factor. Computers in Human Behavior, 95(September 2018), 295-306. https://doi.org/10.1016/j.chb.2018.09.015

Hofacker, C. F., de Ruyter, K., Lurie, N. H., Manchanda, P., \& Donaldson, J. (2016). Gamification and Mobile Marketing Effectiveness. Journal of Interactive Marketing, 34(2016), 25-36. https://doi.org/10.1016/j.intmar.2016.03.001

Högberg, J., Wästlund, E., Aas, T. H., Hjemdahl, K., \& Nordgård, D. (2020). Herding the

Hordes: Using Location-Based Services and Mobile Messaging to Affect Visitor Behavior. Journal of Hospitality \& Tourism Research, 44(5), 870-878. https://doi.org/10.1177/1096348020912449 
Hubert, M., Blut, M., Brock, C., Backhaus, C., \& Eberhardt, T. (2017). Acceptance of Smartphone-Based Mobile Shopping: Mobile Benefits, Customer Characteristics, Perceived Risks, and the Impact of Application Context. Psychology \& Marketing, 34(2), 175-194. https://doi.org/10.1002/mar.20982

Hui, S. K., Inman, J. J., Huang, Y., \& Suher, J. (2013). The Effect of In-Store Travel Distance on Unplanned Spending: Applications to Mobile Promotion Strategies. Journal of Marketing, 77(2), 1-16. https://doi.org/10.1509/jm.11.0436

Ieva, M., Ziliani, C., Gázquez-Abad, J. C., \& D’Attoma, I. (2018). Online versus Offline

Promotional Communication. Journal of Advertising Research, 58(3), 338-348. https://doi.org/10.2501/JAR-2017-040

Kim, T., Barasz, K., \& John, L. K. (2019). Why Am I Seeing This Ad? The Effect of Ad Transparency on Ad Effectiveness. Journal of Consumer Research, 45(5), 906-932. https://doi.org/10.1093/jcr/ucy039

Klabjan, D., \& Pei, J. (2011). In-store one-to-one marketing. Journal of Retailing and Consumer Services, 18(1), 64-73. https://doi.org/10.1016/j.jretconser.2010.09.012

Luo, X., Andrews, M., Fang, Z., \& Phang, C. W. (2014). Mobile Targeting. Management Science, 60(7), 1738-1756. https://doi.org/10.1287/mnsc.2013.1836

Maity, M., \& Dass, M. (2014). Consumer decision-making across modern and traditional channels: E-commerce, m-commerce, in-store. Decision Support Systems, 61(1), 34-46. https://doi.org/10.1016/j.dss.2014.01.008

Melumad, S., \& Pham, M. T. (2020). The Smartphone as a Pacifying Technology. Journal of Consumer Research, 0. https://doi.org/10.1093/jcr/ucaa005

MMA. (2019). Location terminology guide: The language of location. Retrieved from http://www.mmaglobal.com/documents/location-terminology-guide\%0A

Molitor, D., Reichhart, P., Spann, M., \& Ghose, A. (2015). Measuring the Effectiveness of Location-Based Pull Advertising: A Randomized Field Experiment. SSRN Electronic Journal. https://doi.org/10.2139/ssrn.2645281

Pantano, E., \& Gandini, A. (2018). Shopping as a "networked experience": an emerging framework in the retail industry. International Journal of Retail and Distribution Management, 46(7), 690-704. https://doi.org/10.1108/IJRDM-01-2018-0024

Pantano, E., \& Priporas, C.-V. (2016). The effect of mobile retailing on consumers' purchasing experiences: A dynamic perspective. Computers in Human Behavior, 61, 548555. https://doi.org/10.1016/j.chb.2016.03.071

Parasuraman, A., \& Colby, C. L. (2015). An Updated and Streamlined Technology Readiness Index. Journal of Service Research, 18(1), 59-74. https://doi.org/10.1177/1094670514539730 
Patsiotis, A., Atik, M., \& Perrea, T. (2020). The influence of m-marketing tools on consumer buying process: evidence from the dining sector. International Journal of Retail \& Distribution Management, 48(10), 1037-1056. https://doi.org/10.1108/IJRDM-06-20180109

PushCrew. (2018). The State of Web Push Notifications. Retrieved from https://medium.com/the-pushcrew-journal/2018s-most-comprehensive-report-on-pushnotification-usage-and-use-cases-dd12a47111b7

Rogers, E. M. (1983). Diffusion of Innovation. New York: The Free Press.

San-Martín, S., Prodanova, J., \& López Catalán, B. (2016). What makes services customers say "buy it with a mobile phone"? Journal of Services Marketing, 30(6), 601-614. https://doi.org/10.1108/JSM-02-2015-0081

Scharl, A., Dickinger, A., \& Murphy, J. (2005). Diffusion and success factors of mobile marketing. Electronic Commerce Research and Applications, 4(2), 159-173. https://doi.org/10.1016/j.elerap.2004.10.006

Shankar, V., Kleijnen, M., Ramanathan, S., Rizley, R., Holland, S., \& Morrissey, S. (2016). Mobile Shopper Marketing: Key Issues, Current Insights, and Future Research Avenues. Journal of Interactive Marketing, 34, 37-48. https://doi.org/10.1016/j.intmar.2016.03.002

Shankar, V., Venkatesh, A., Hofacker, C., \& Naik, P. (2010). Mobile marketing in the retailing environment: Current insights and future research avenues. Journal of Interactive Marketing, 24(2), 111-120. https://doi.org/10.1016/j.intmar.2010.02.006

Sohn, S., Seegebarth, B., \& Moritz, M. (2017). The Impact of Perceived Visual Complexity of Mobile Online Shops on User's Satisfaction. Psychology \& Marketing, 34(2), 195-214. https://doi.org/10.1002/mar.20983

Statista. (2019). E-commerce share of total global retail sales from 2015 to 2023 . Retrieved from https://www.statista.com/statistics/534123/e-commerce-share-of-retail-salesworldwide

Sultan, F., \& Rohm, A. (2005). The coming era of "brand in the hand" marketing. MIT Sloan Management Review, 47(1).

Tang, D., Yang, Y., Yan, Y., \& Zhou, M. (2016). What determines online consumers to migrate from PCs to mobile devices? - An empirical approach on consumers' internet cross-channel behaviours. International Journal of Services Technology and Management, 22(1/2), 46. https://doi.org/10.1504/IJSTM.2016.077656

Tong, S., Luo, X., \& Xu, B. (2020). Personalized mobile marketing strategies. Journal of the Academy of Marketing Science, 48(1), 64-78. https://doi.org/10.1007/s11747-019-00693-3

Tsang, M. M., Ho, S.-C., \& Liang, T.-P. (2004). Consumer Attitudes Toward Mobile Advertising: An Empirical Study. International Journal of Electronic Commerce, 8(3), 6578. https://doi.org/10.1080/10864415.2004.11044301 
Tseng, F.-C., Cheng, T. C. E., Li, K., \& Teng, C.-I. (2017). How does media richness contribute to customer loyalty to mobile instant messaging? Internet Research, 27(3), 520 537. https://doi.org/10.1108/IntR-06-2016-0181

Tseng, F., Cheng, T. C. E., Yu, P.-L., Huang, T.-L., \& Teng, C.-I. (2019). Media richness, social presence and loyalty to mobile instant messaging. Industrial Management \& Data Systems, 119(6), 1357-1373. https://doi.org/10.1108/IMDS-09-2018-0415

Van der Heijden. (2004). User Acceptance of Hedonic Information Systems. MIS Quarterly, 28(4), 695. https://doi.org/10.2307/25148660

Venkatesh, Morris, Davis, \& Davis. (2003). User Acceptance of Information Technology: Toward a Unified View. MIS Quarterly, 27(3), 425. https://doi.org/10.2307/30036540

Verhoef, P. C., Stephen, A. T., Kannan, P. K., Luo, X., Abhishek, V., Andrews, M., ... Zhang, Y. (2017). Consumer Connectivity in a Complex, Technology-enabled, and Mobileoriented World with Smart Products. Journal of Interactive Marketing, 40, 1-8. https://doi.org/10.1016/j.intmar.2017.06.001

Wang, R. J.-H., Malthouse, E. C., \& Krishnamurthi, L. (2015). On the Go: How Mobile Shopping Affects Customer Purchase Behavior. Journal of Retailing, 91(2), 217-234. https://doi.org/10.1016/j.jretai.2015.01.002

Xu, H., Teo, H., Tan, B. C. Y., \& Agarwal, R. (2009). The Role of Push-Pull Technology in Privacy Calculus: The Case of Location-Based Services. Journal of Management Information Systems, 26(3), 135-174. https://doi.org/10.2753/MIS0742-1222260305

Zhang, J., \& Mao, E. (2008). Understanding the acceptance of mobile SMS advertising among young Chinese consumers. Psychology and Marketing, 25(8), 787-805. https://doi.org/10.1002/mar.20239 